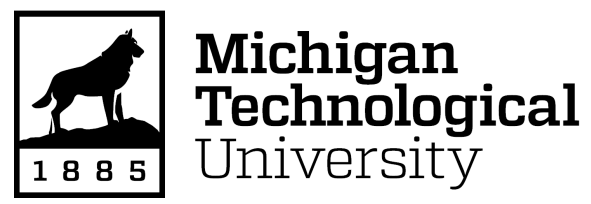

Michigan Technological University Digital Commons @ Michigan Tech

Dissertations, Master's Theses and Master's Reports

2016

Clusivity in Presidential Discourse: A Rhetorical Discourse Analysis of State-of-the-Nation Addresses in Ghana and the United States

Stephen K. Dadugblor

Michigan Technological University, skdadugb@mtu.edu

Copyright 2016 Stephen K. Dadugblor

Recommended Citation

Dadugblor, Stephen K., "Clusivity in Presidential Discourse: A Rhetorical Discourse Analysis of State-ofthe-Nation Addresses in Ghana and the United States", Open Access Master's Thesis, Michigan Technological University, 2016.

https://doi.org/10.37099/mtu.dc.etdr/123

Follow this and additional works at: https://digitalcommons.mtu.edu/etdr

Part of the African Languages and Societies Commons, English Language and Literature Commons, Other Rhetoric and Composition Commons, and the Rhetoric Commons 


\title{
CLUSIVITY IN PRESIDENTIAL DISCOURSE: A RHETORICAL DISCOURSE ANALYSIS OF STATE-OF-THE-NATION ADDRESSES IN GHANA AND THE UNITED STATES
}

\author{
By
}

Stephen K. Dadugblor

\begin{abstract}
A THESIS
Submitted in partial fulfillment of the requirements for the degree of MASTER OF SCIENCE

In Rhetoric, Theory and Culture
\end{abstract}

MICHIGAN TECHNOLOGICAL UNIVERSITY

2016

(C) 2016 Stephen K. Dadugblor 
This thesis has been approved in partial fulfillment of the requirements for the Degree of MASTER OF SCIENCE in Rhetoric, Theory and Culture.

Department of Humanities

Thesis Advisor: $\quad$ Victoria L. Bergvall

Committee Member: Abraham Romney

Committee Member: $\quad$ Craig Waddell

Committee Member: $\quad$ Kari B. Henquinet

Department Chair: Ronald Strickland 
To my brother, Michael K. Dadugblor, who gave up much, that I might have so much more 


\section{TABLE OF CONTENTS}

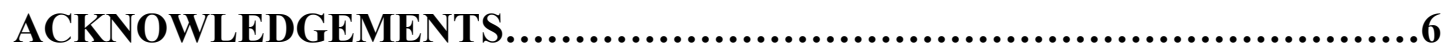

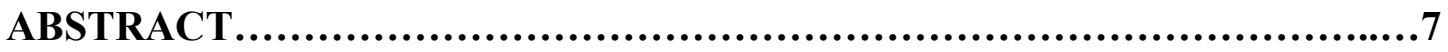

CHAPTER ONE: THE ROLE OF LANGUAGE IN POLITICS .................9

1.1. INTRODUCTION .................................................

1.2. RESESEARCH QUESTIONS......................................

1.3.SIGNIFICANCE OF THE STUDY ................................22

1.4. STATE OF THE NATION ADDRESSES AS PRESIDENTIAL

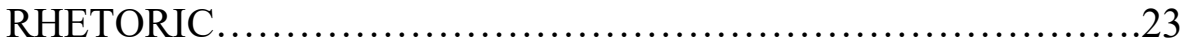

\section{CHAPTER TWO: THEORETICAL FRAMEWORK AND}

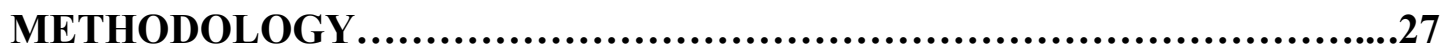

2.1. RHETORIC AS AN APPROACH TO TEXT ANALYSIS............27

2.2. CRITICISM OF RHETORIC AS PERSUASION....................29

2.3. CRITICAL DISCOURSE ANALYSIS/STUDIES...................31

2.4. CRITICISMS AGAINST CRITICAL DISCOURSE ANALYSIS/STUDIES.................................................. 33

2.5. PRONOUNS IN POLITICAL DISCOURSE........................36

2.6. DATA SELECTION.............................................

2.7. METHODOLOGY ................................................

CHAPTER THREE: ANALYZING STATE OF THE NATION

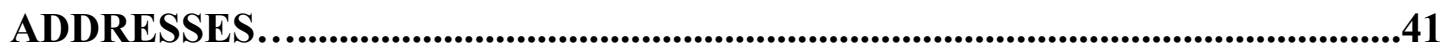

3.1. ANALYZING PRESIDENT MAHAMA’S SONA....................41

3.1.1. SUMMARY OF ANALYSIS OF PRESIDENT MAHAMA'S

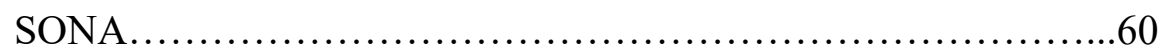


3.2. ANALYZING PRESIDENT OBAMA'S SONA.....................61

3.2.1. SUMMARY OF ANALYSIS OF PRESIDENT OBAMA'S SONA.

3.3. CULTURAL IMPACTS ON CONTEMPORARY GHANAIAN COMMUNICATION ..........................................

CHAPTER FOUR: RE-ENVISIONING RHETORIC AND CDA IN AFRICAN

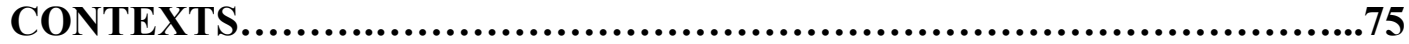

4.1. SUMMARY ................................................. 75

4.2. SUGGESTIONS FOR FUTURE RESEARCH.....................78

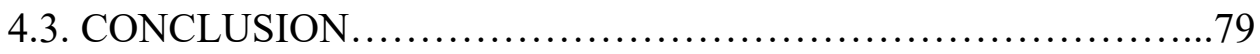

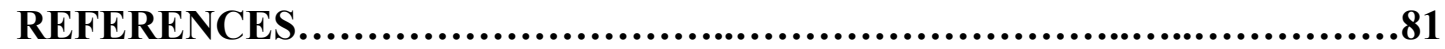




\section{ACKNOWLEDGEMENTS}

I am hugely indebted to my advisor, Dr. Victoria Bergvall, for her mentoring, dedication and prompt feedback on my work. Her guidance was invaluable, and her assistance and extra interest in my development as a budding academic have been particularly helpful. I am immensely grateful.

I thank, also, my thesis committee members-Dr. Craig Waddell, Dr. Abraham Romney, and Dr. Kari Henquinet—-for their insightful feedback and questions that forced me to think beyond the easy answers to more compelling reasons for my claims.

To my friends Elias Adanu and Umar Mohammed, thank you for the incisive questions and suggestions during the course of this project. Also, my weekly discussions with Nancy Henaku, Tolulope Odebunmi, and Yunana Ahmed during our Critical Discourse Analysis (CDA) Reading Group meetings have been beneficial. I thank them for their contributions to discussions which clarified my understanding of concepts.

Finally, I am grateful to God Almighty for his grace thus far. 


\begin{abstract}
This thesis examines the ways in which rhetors in presidential discourse simultaneously associate with and dissociate from their audiences in an attempt to consolidate power while subtly masking their actions. Drawing on comparative rhetoric and Andrus' (2013) Rhetorical Discourse Analysis (RDA) that combines rhetoric and (critical) discourse analysis, I analyze the expressive values of selected lexical items, and the inclusive and exclusive uses of "we" in selected State of the Nation/Union Addresses in Ghana and the United States. I argue that presidents' unique position during these speeches as both heads of nations and heads of their political parties presents a challenge in their twin roles as assessors of national performance and promoters of policies, with the result that they associate with different audiences for purposes of political gain, based on whether the stance is epideictic (celebrating unity) or deliberative (setting a policy agenda). Further, a focus on the Ghanaian text uncovers the complexities inherent in such adopted Western rhetorical genres, and yet adapted Ghanaian discursive practices. I draw on these complexities to call for more attention to traditional socio-cultural norms and expectations that affect borrowed rhetorical practices in particularly postcolonial African contexts, as a way of re-envisioning nuances of power relations and rhetorical strategies in these milieux. This, I argue, could be a significant contribution to scholarship in both comparative rhetoric and Critical Discourse Analysis in nonWestern contexts. The study also demonstrates how an interdisciplinary approach such as RDA could unravel aspects of such speeches-persuasion and power
\end{abstract}


differentials aimed at agenda setting — that a single approach might otherwise probably not reveal.

\section{Keywords:}

State of the union address, Critical Discourse Analysis, comparative rhetoric, Ghana, clusivity, political discourse, rhetorical discourse analysis, presidential rhetoric, pronouns 


\section{CHAPTER ONE: THE ROLE OF LANGUAGE IN POLITICS}

\subsection{Introduction}

The recognition that language and politics are intricately interlinked has been fundamental to studies in rhetoric and many strands of discourse studies, particularly Critical Discourse Analysis. Scholars have often emphasized the role of language as constitutive of politics and as a means by which we come to understand political behavior. Chilton (2004), for instance, has argued that language is a major means by which political actors share a common view with their audience regarding "what is useful-harmful, good-evil, just-unjust” (p. 199). To Chilton, political discourse focuses on representation, by which political actors employ language to legitimize their positions and justify their actions. This connection between language and politics becomes significant in analyses that seek to understand how discourses are represented, produced and reproduced. Critical Discourse Analysis (CDA) offers an important avenue for understanding such a connection in politics and language, in talk and text, in performance and semiotics. Most CDA research has varying emphases: for instance, among others, there is multimodal discourse (Kress \& van Leeuven, 2002), which investigates how visual, alphabetic, gestural and aural communication modes are selected and harnessed to perpetuate power and domination; discourse-historical approach (Wodak, 2001), which explores the historical formation and change of discursive practices in relation to inequality in society; social cognition (van Dijk, 1993), with a focus on how discourse structure and social structure are mediated by mental models; and social process (Fairclough, 
2013), in which there is a nexus between discourse and social institutional practices, with both shaping each other. What is common to these, and other approaches to CDA, Lin (2013) suggests, is CDA's principal focus on "different forms of social inequality and domination and subordination that are being produced and reproduced through language and discourse, and its commitment to working towards effecting change and improvement of such situations" (p. 1466). Thus, CDA could be a useful tool for understanding not only the ways in which language is used in politics to associate with some audiences and dissociate from others as a way of consolidating power, but also as a means of re-envisioning how that same power works.

To associate with and dissociate from audiences in political discourse, speakers include audience members affiliated to their political ideology, and exclude others who are outside their ideological group. As Wieczorek (2013) notes, "human ability to affiliate with other [sic] and differentiate self from other [sic] constitutes a salient aspect of a group's existence and organization" (p. 11). She explains further that individuals are excluded so that the status of majority groups can be preserved. Association and dissociation are, for example, realized linguistically through the concept of clusivity - the linguistic construction of the "roles of actors in a speech event with respect to each other, as well as the relationship between the speaker, and in-group and out-group members in particular" (Wieczorek, 2012, p. 28). Given that electoral discourse, in particular, and political discourse, in general, employ inclusion and exclusion based on ideological differences and strategic interests, it is important for political discourse analysts to investigate clusivity in speeches such as the national 
State of the Union/Nation addresses ${ }^{1}$, especially when by their nature, such addresses are intended to be inclusive in tone and approach: they are intended to be more of national addresses than partisan political speeches, yet they valorize the agendas of the political parties.

Indeed, while political discourse may both exploit and conceal power differentials, it is also very often intended to persuade particular audiences to take certain courses of action. A useful approach for the analysis of the persuasiveness of political speeches is rhetorical analysis. Rhetoric, in its many manifestations, has traditionally focused on ethical speaking as well as the effective persuasive strategies used by rhetors to construct and convey messages in particularly situated contexts. In both classical and contemporary traditions, rhetoric continues to be used as an analytical method for the analysis of texts, including political speeches. In the classical tradition, for instance, concepts such as rhetorical appeals proposed in Aristotle's Rhetoric (2006) are used by scholars to analyze the persuasiveness of speeches (cf. Cheng, 2006; Roitman, 2014). A growing body of scholarship also relies on contemporary rhetorical approaches like Burke's (1969) identification as a lens through which the persuasive power behind political speeches can be analyzed. For instance, Nelson (2009) argues for the significance of the concept of Burkean identification through an analysis that demonstrated how President Bush and the Republican Party convincingly used

\footnotetext{
${ }^{1}$ In this research work, I use SONA as an abbreviation for both "State of the Nation Address" and "State of the Union Address" as both are essentially the same, the former used in Ghana, and the latter in the United States.
} 
identification as a persuasive strategy to canvass for the votes of gay and lesbian groups in the 2000 presidential elections in the United States.

Both CDA and rhetoric as methodological approaches are often separately employed in the analysis of texts: the former, in investigating the role of language in the production and reproduction of power, and some strands of the latter, in examining how rhetors make meaning in texts. In recent times, however, there have increasingly been calls for scholars to pay closer attention to the advantages that both rhetoric and discourse analysis stand to gain if used together in an interdisciplinary manner. These calls are premised on the commonalities both approaches share. Several articles in Johnstone and Eisenhart's (2008) volume, Rhetoric in Detail, have emphasized this connection between rhetoric and discourse analysis. In the introductory chapter to the volume, Eisenhart and Johnstone contend that "[t]he approaches to discourse analysis we offer and exemplify in this book are meant to illustrate the many productive ways close attention to language can pay off for rhetoricians" (2008, p. 14). This view of interdisciplinarity between the two approaches has, further, been echoed by other scholars. In a discussion of the relevance of CDA for rhetoric and composition, Huckin, Andrus and Clary-Lemon (2012) insist that CDA, given its focus on linguistic detail, and capacity to blend with other approaches, can be usefully employed together with methodologies in rhetoric and composition. CDA, they suggest, could be valuable in "providing a repertoire of context-sensitive tools that can assist researchers, instructors, and students in interrogating power and ideology as they are indexed and produced in specific instances of public discourse" (p. 110). 
More recently, Andrus (2013) has emphasized that while discourse analysis focuses on the micro details of texts, rhetoric concerns itself with macro processes, that is "speaker authority, audience response, persuasion and other effects of texts, the rhetor's goals, contextually situated interaction, and the like" (p. 4976), and thus could be usefully employed in an approach she calls Rhetorical Discourse Analysis (RDA). Although both rhetorical analysis and linguistic analysis focus on micro details, they seem to have different goals in focusing on such details: rhetoric, on lexical items geared towards persuasion, and CDA, on those linguistic details aimed at the exercise of power. The RDA approach used here combines the focus of both rhetoric and CDA in a complementary manner. Andrus' RDA is in tandem with van Leeuven's (2005) integrationist model of interdisciplinarity, in which “the component disciplines [of rhetoric and (critical) discourse analysis] [...] play specific, complementary roles in a larger whole" (p. 15).

Given the foregoing, this thesis takes up the call of such an RDA approach in investigating the ways in which presidential rhetoric, constituted in State of the Union/Nation Addresses (hereafter SONA) could both, at once, attempt to persuade audiences by associating with them, and at the same time, dissociate from them in an attempt to conceal power differentials and promote partisan policies. Rhetoric, and particularly CDA, I suggest, can illuminate both the persuasion and power differentials behind these speeches. My research project undertakes an analysis of selected SONA of President John Mahama of Ghana and President Barack Obama of the United States. I also situate this study within comparative rhetoric which has 
come to be associated with the rhetorical practices of people of diverse cultural contexts. The United States and Ghana are two different geo-political and social contexts, not only with differences in electoral practices, public engagement in political discourse, public trust for political actors, among others, but also with nuanced differences in rhetorical practices. Rather than pit two presidential rhetorical traditions against each other, the comparative rhetorical approach adopted for this study is intended to "cultivate a mode of thinking that moves away from divides and binaries abstracted from context" by advocating for "nuanced analysis and discursive open-endedness" (Mao et al. 2015, p. 240). As Mao et al. (2015) advocate in their "Manifesting a Future for Comparative Rhetoric," comparative rhetoricians need to "use the trope of comparison to discover and articulate gaps, interstices, and intersectionalities and to determine what is important [emphasis added] and what is merely available or present for any tradition" (p. 240). This aim of comparative rhetoric echoes an earlier view by Hum and Lyon (2013) that comparative rhetoric should be concerned with "the cultural bases [emphasis added] of discursive power and the ways it privileges some statements and strategies in the production of knowledge and the reproduction of power" (p. 154). The fact that African rhetorical practices have not received much attention in scholarship (unless one includes African American rhetoric) (Hum \& Lyon, 2013, p. 161) makes the exploration of rhetorical practices within a specifically Ghanaian context (in addition to an American context) all the more important in this comparative endeavor. 
Any comparative enterprise is necessarily fraught with the challenge of avoiding a normative standard by which the elements of the comparison are evaluated. According to Friedman (2011), "[i]n describing one thing in terms of another, comparison assumes knowledge of the one to which the other is compared. The known then operates as measure of the unknown, standing in an unequal relationship to it" (p. 754). It is such problems of comparison that make a comparative study of texts from different cultures as this one seem unjustifiable. However, the fact that the texts from both cultures will be analyzed on their own terms and not one against the other makes the research a significant contribution to comparative rhetorical studies. Moreover, the study will pay close attention to how the rhetorical and linguistic strategies identified are used in each of the cultures under study.

Studying the rhetorical practices of particular cultures on their own terms ensures that hierarchies of comparison are dismantled. Drawing on Edward Schiappa, Mao (2014) makes a distinction between facts of essence and facts of usage in rhetorical studies. The former, he notes, are concerned with questions of "What is X?" while the latter refers to "How is X used in specific situations?" He advocates for a shift from the essentialist notions of the "What is?" question to how in comparative rhetoric, with a focus on facts of usage, and facts of non-usage, that is, "linguistic and other symbolic behaviors and experiences that have been disqualified, forgotten, or deemed something other than rhetoric" (p. 449). He explains that 
$[\mathrm{t}] \mathrm{o}$ genuinely embrace non-Euro-American rhetorical practices and their ways of knowing and speaking and to productively engage the cultural mappings that inform discursive fields, we must part ways with the perennial yet parochial longing for facts of essence. For comparative rhetoricians, the central question to ask then is not "What is rhetoric in/and for these other cultures?" but "What does the other do in/with rhetoric, and how does the other do it?" (p. 450)

While Mao's focus is on those elements of a culture that have for long been deemed non-rhetorical, these SONAs used in both Ghanaian and American contexts are already rhetorical, with cultural variations that might provide insights of "nonrhetorical" elements especially within the Ghanaian context. Also, I focus on facts of usage, and not necessarily on facts of non-usage, since the former appears to be more appropriate for the analysis. Mao's approach enables us to step beyond the problem of creating binaries in comparisons and to study the rhetorical practices of cultures on their own terms. Through "thick description, dialogism, and consciousness," Mao suggests that we may uncover what he calls the ecology of "historicity, specificity, and incongruity," which are the socio-cultural exigencies that determine rhetorical practices, the occasions of use of particular rhetorics, and the clashes and mergers that have given birth to certain rhetorics (2014, p. 450-451).

The methodological approaches used in any research assume a frame of reference for a researcher, the worldviews through which research problems are shaped and 
analyzed, as well as the questions that can be asked and answered. Especially in a comparative project such as this, there is the danger of studying cultures through the lens of research methodologies developed outside each culture respectively. In her book Decolonizing Methodologies, Tuhiwai Smith (2012), focusing on the Maori cultures of New Zealand, argues for a shift away from colonizing research practices in which the Other-non-Western people in particular—are studied through methodological and research approaches developed in the West. One way she advocates that this shift be made is through the concept of reframing, which takes its impetus from the realization that indigenous people who have been negatively framed and studied by the standards of others must begin to take control of investigating indigenous problems and solutions. This will involve "the way indigenous people write or engage with theories and accounts of what it means to be indigenous" ( $p$. 155). Framing a problem in a way that ignores the socio-cultural and political factors that have shaped a people's realities could be colonizing, since solutions are provided that are based on standards foreign to the culture. A challenge, however, of such indigenizing enterprise is that societies have always been in constant flux, with cultural contacts enabled by colonialism and the increasingly globalizing forces of the internet, migration and trade. These pose a challenge to notions of cultural authenticity and "pure forms." Especially within a postcolonial Ghanaian context, precolonial traditional norms, including those of communication, have been heavily supplanted by Euro-American systems. This further makes a recovery of authentically Ghanaian traditional socio-cultural norms of communication nearly impossible. The 
hybridity that a postcolonial experience affords becomes significant within the Ghanaian context as the focus will no longer be on pure Ghanaian cultural forms of communication and hierarchies of power, but rather on the nuances of ways of speaking and writing that the Ghanaian contact with colonialism, and indeed Western systems of communication, could be said to have engendered.

Indeed, Smith's ideas above echo Mao's about the questions that can be asked of a people's rhetorical practices. Studying a people on their own terms, as both Smith and Mao suggest, would involve understanding their particular social realities, and indigenizing research practices that take into account those realities. This thesis thus takes into account the different socio-cultural and political realities within which the texts are produced in order that the analysis can better reflect the study of the cultures on their own terms.

Although comparative rhetoric has come to be associated with the study of the rhetorical practices of people of non-Western cultures in general, the approach adopted here moves beyond the rhetorical practices within a Ghanaian (non-Western) context to that of an American context as well. The data for the analysis will be selected SONA of the presidents. The choice of the addresses is premised on the assumption by Shogan (2015) that "[t]he State of the Union address is not primarily a partisan speech or document" (p. 7). A critical feature of the SONA, he posits, is that it is characterized by a bipartisan tone, an element he contends distinguishes such addresses from all other types of presidential rhetoric (ibid.). Presumably, this 
bipartisanship is as a result of the fact that the address, unlike all other presidential speeches, is read to a Congress (in the case of the United States) or to Parliament (in Ghana) where opposing political parties are present. It is also televised, and addresses not only the power elite, but the whole nation. Shogan's (2015) claim of bipartisanship in tone of the SONA is made with the United States in mind; however, this assumption could as well apply to Ghana. The Structural Adjustment Programs (SAPs) of the 1980s promoted by the World Bank and the International Monetary Fund (IMF), with support from the United States, forced most African countries, including Ghana, to adopt economic and development policies and practices of Western countries. The 1992 4th Republican Constitution of Ghana followed on the heels of such policies. The provisions in the Constitution for a State of the Nation address is, arguably, an adoption of the practice from the United States. ${ }^{2}$ This assumption makes it important to test Shogan's claim within the Ghanaian context so as to establish how borrowed rhetorical elements and genres play out in other cultural contexts.

The constitutional mandate for the address in both countries states the purpose to be an address on "the state of the nation/union." Framing this not as an election

\footnotetext{
${ }^{2}$ It is worth mentioning that while Ghana's earlier constitutions right after independence had been modelled after its former colonial master's, Britain's, the practice of the State of the Nation address is most likely an adoption of the genre in the United States, considering that the United States was one of the external influences on Ghana's move toward democratization. Besides, except for "a speech from the throne," Britain has no such tradition of a State of the Nation address as the United States does. It is based on this reasoning that the assumption is made.
} 
campaign speech, for instance, the presidents as leaders of each of their nations and political parties have a dilemma to contend with: how to construct the state of the nation in a way that is inclusive of all, including political opponents, while entrenching their position in their own political party, and also presenting a positive image of themselves. Again, given Shogan's (2015) bipartisanship claim, it is important to investigate how such a tone is composed in a manner that could both persuade audiences while dissociating from certain elements (especially political opponents) so as to exclude them, thus consolidating the power of the presidents and their parties. The fact that there are often counter/opposition statements after the SONA in the US and Ghana presupposes that a president's account of the state of the nation might be deemed to be a false or incomplete reflection of the state of affairs; political actors on the other side of the divide may have different accounts of events, hence the opposition response. ${ }^{3}$ As a persuasive text then, the SONA, it could be argued, must be inclusive of opposing views in its use of language as to make it as bior non-partisan as possible. It is within this context that the present study focuses on the strategies that are used to include and persuade, and at the same time exclude

${ }^{3}$ For instance, the 2016 opposition response in Ghana, delivered on February 29, 2016 by the flagbearer of the opposition New Patriotic Party (NPP), Nana Addo Dankwa Akufo-Addo, was titled "The Real State of the Nation-A Nation in Crisis," and sought to address socio-economic issues that the opposition NPP claimed the president had glossed over in his speech. That same day, the government announced its intention to offer a rebuttal, showing the very partisan and political nature of such speeches. 
some of the audience from the discourse as a way of determining responsibility and legitimizing power.

\subsection{Research Questions}

The thesis is guided by the following three questions:

1. In what ways are linguistic and rhetorical strategies used by each president to communicate association with their audiences and persuade them?

2. How are linguistic and rhetorical strategies employed in the speeches to dissociate from the audiences for purposes of political gain?

3. In what ways are association and dissociation in the Ghanaian text particularized to the African cultural context from which the speech originates?

Within the scope of this project, I narrow the linguistic strategies to inclusive and exclusive uses of the first-person English pronoun "we" as these show association and dissociation of audiences. Also, I focus on the expressive values of lexical items as these tell us much about the positive and negative associations that the rhetor places on the words, and how the words in turn create particular ideological references that either include or exclude certain audiences. Further, regarding rhetorical strategies, I focus on two of Aristotle's three occasions of rhetoric, viz., epideictic and deliberative rhetoric. Both are suitable for the analysis of the SONA since presidents use the speech as a means of celebrating the values and achievements of the citizenry, and also outline their policy proposals, the former as a form of epideictic rhetoric, and 
the latter as deliberative rhetoric. As types or occasions of rhetoric, both become useful in a project as this which seeks to investigate how the presidents include or exclude their audiences depending on what type of rhetoric is relevant for their own purposes.

\subsection{Significance of the Study}

It is hoped that this study will have political relevance to individuals and organizations by revealing both rhetorical and linguistic elements contained in the SONAs that make them a type of presidential discourse not only for the persuasion of a citizenry about the state of a nation at a given time, but also as speeches that could conceal power differentials and biases of presidents as leaders of their party who are in a politically difficult position — as objective leaders of nations and also as leaders of their political parties. Also, the comparative rhetoric approach adopted will help reveal the similarities and differences in the speeches in two different socio-political contexts, and add to literature in comparative rhetoric and CDA on the rhetorical practices in particularly a non-Western context. Further, scholars to whom the analysis of rhetoric is central will find the study a useful addition to a growing body of work on the nature of this unique type of presidential discourse, especially within the Ghanaian case, where the genre of the SONA has been manifestly underresearched. The project will also reveal the veiled power relations in the SONA while illuminating how scholars can better appreciate the role of language in the construction of the state so that policy evaluations based on such addresses can better 
take into account political party positionality in them. Finally, the research project will contribute to the reflexivity of colonizing methodologies.

\subsection{State of the Nation Addresses as Presidential Rhetoric}

Presidential rhetoric has increasingly been the subject of scholarly interest given that through it, presidents establish a relationship between themselves and the public by communicating policies, plans and accomplishments to citizens. Zarefsky (2004) argues that it is a means by which a president defines social and political reality and the contexts by which citizens come to understand this reality (p. 611). One example of presidential addresses is the State of the Nation address, which in the United States, for example, is a constitutional requirement geared towards checks and balances. Specifically, the United States Constitution stipulates that the President "shall from time to time give to the Congress information of the State of the Union, and recommend to their consideration such measures as he shall judge necessary and expedient" (U.S. Const. Art. II, § 3). Over the past two centuries of its existence, the SONA in the United States has undergone a number of changes in form, content and delivery. For instance, it has moved from an address to only members of Congress to both Congress and the American public; it has morphed from its initially lengthy nature to a much shorter delivery (probably because of shorter attention span of the audiences, and expectations of the audience for shorter speeches); and its delivery has also been significantly influenced by technological advancement: it is now televised rather than simply read or sent to Congress (Teten, 2003; Shogan, 2015). These 
changes notwithstanding, it continues to be considered by Congress as the most important annual speech by the president (Shogan, 2015, p. 1). Given this importance, unsurprisingly, numerous studies have investigated its content and structure, as well as the rhetorical strategies employed in them by U.S. presidents over time. For example, presidents have used the SONA as a means to reinforce the values of the American people (Sowinska, 2013) and as a self-presentational strategy for their own political ambitions (Smith, Whitehead, Melo, Correa, \& Inch, 2014). Smith, et al. (2014) note that SONAs have been used by modern American presidents (from the 20th century onwards) as a way of promoting and ingratiating themselves with their audiences. This, they claim, is as a result of the expectation that presidents be charismatic during such speeches.

In their seminal work on various forms of presidential addresses in Presidents Creating the Presidency, Campbell and Jamieson (2008) argue that the SONA is "central to the maintenance of the presidency" itself as it enables the president to act as a "national historian, keeper of the national identity, and voice of national values" (p. 164). A president's role as chronicler of the nation's history, as well as his/her position as both head of political party and head of state raises some critical questions. To what extent does the president act in the interest of the political party of which $\mathrm{s} / \mathrm{he}$ is leader? In what ways might national interest be at variance with the president's political party's interest? These considerations become all the more important when we consider Campbell and Jamieson's (2008) account of one of 
President Truman's addresses. They report that while the SONA is often designed to be bipartisan, some, like Truman's 1948 address, were anything but conciliatory:

Truman's 1948 message, for example, was a blueprint for the coming campaign. Truman aide George Elsey had recommended that the address be "controversial as hell, must state the issues of the election, must draw the line sharply between Republicans and Democrats. [emphasis added] The Democratic platform will stem from it, and the elections will be fought on the issues it presents." The speech was crafted to achieve those ends. (Campbell \& Jamieson, 2008, p. 155)

Clearly, the SONA could be and has actually sometimes been used for political gain, in which case bipartisanship, consensus and cooperation become inconsequential in a president's assessment of national performance. In other words, the SONA could be used to actively pursue partisan interests in a manner that excludes opposing parties as could be seen in the citation above.

Most studies on the SONA have largely focused on the United States, arguably in part because of the address's over two-century-long history in the United States. There are, however, few studies on the structure, content and uses to which similar addresses have been put in other countries. For instance, scholarship on the address in Ghana has largely relied on the speeches as a basis for policy formulation and evaluation (e.g. Essel et al. 2014; Rosencrans, 2014; Harutyunyan \& Odame, 2015). However, since discursive choices made by a speaker are political, it is important to 
investigate rhetorical and linguistic aspects of the address in Ghana, which could, in turn, complement the policy evaluation efforts of such scholars. Just as the president of the United States addresses Congress, the president of Ghana is required constitutionally to "at the beginning of each session of Parliament and before a dissolution of Parliament, deliver to Parliament a message on the state of the nation" (Const. of Ghana, Art. 67). The SONA in Ghana is, arguably, derivative of the address in the United States. For instance, only recently have opposition political party responses to the address, as is done in the United States, been seen in Ghana. Such responses could be traced to the idea of opposition responses to the SONA that Shogan (2015) reports as having started in the United States in 1966 (p. 12). Based on these similarities, it is important that this study interrogate the addresses in both contexts to uncover nuances of the genre occasioned and shaped by cultural influences especially, within the Ghanaian context.

The rest of this thesis is organized as follows. Chapter Two deals with the theoretical framework and methodology used in the study. Here, I explore both rhetoric and Critical Discourse Studies as separate theoretical frameworks and explain why it is useful to study such speeches through an interdisciplinary lens that brings both approaches together. In the same chapter, I explain the methods used in the analysis. Chapter Three then applies the methods identified in Chapter Two to the speeches, through an extensive analysis of excerpts from the selected speeches. Chapter Four, the final chapter, discusses the findings and implications of the analysis, and offers some suggestions for future research. 


\section{CHAPTER TWO: THEORETICAL FRAMEWORK AND METHODOLOGY}

This chapter explores the theoretical framework used for the analysis - rhetoric and Critical Discourse Analysis. It also provides details on the methodology used.

\subsection{Rhetoric as an Approach to Text Analysis}

In his Rhetoric, Aristotle (2006) delineates three oratorical occasions based on the time with which each occasion of rhetoric is concerned, and on an audience's decision to take a particular course of action if they are persuaded. The occasions, also known as types or species of rhetoric, are deliberative or legislative (concerned with the future), judicial or forensic (based on decisions about the past time), and epideictic rhetoric (on the present time). Deliberative rhetoric is typically geared towards taking a course of action that is in the interest of the audience. Forensic rhetoric seeks justice as its main goal, while epideictic rhetoric praises or blames a subject (Aristotle, 2006, p. 20). Based on some perceived limitations, Aristotle's ideas of these occasions have been critiqued and extended by scholars, including George Kennedy, who, in his introduction to Rhetoric (2006), expands the sphere of epideictic rhetoric to include considerations of "its role in the instilling, preservation, or enhancement of cultural values" (Aristotle, 2006, p. 22). Such celebration of values is consistent with Shogan's (2015) claim that the SONA in the United States, for example, is, setting aside policy proposals, a meditation on goal statements and the values of the American people. 
While Aristotle's classification of rhetoric explained how rhetors construct texts, the framework has been useful for analytical purposes as well. However, in spite of its widespread use, not all scholars agree on the universality of the application of the Aristotelian framework to societies from outside Euro-American contexts. The notion of universality of methodologies is often plagued with imperialism, and is increasingly untenable given particularities that are not shared by people everywhere. Further, the question of ownership of the universal standard poses some challenge to the claim that one mode of speech or writing and analysis could be universally applied. Indeed, while the occasions of rhetoric — and rhetorical appeals_-identified by Aristotle are available in many cultures before and beyond Greek and, indeed, Western contexts, different cultures might have alternative explanations for what constitutes an appeal to ethos, for example. ${ }^{4}$ The foregoing argument presumably makes an application of Aristotle's framework to the SONA within a Ghanaian context unjustifiable. However, when we consider that the SONA is not native to Ghana, but like forms of its governance system, is a Western adoption, it becomes important why such an Aristotelian approach could be applied to the SONA in Ghana, without much challenge. In doing this, the goal will be to determine how the adoption of the genre of the SONA could possibly have been influenced by traditional, precolonial Ghanaian norms and expectations of communication. The success of its

${ }^{4}$ Consider Bokor's (2014) application of the rhetorical appeals to traditional drums in African countries, where he argues, along comparative rhetoric lines, that rather than being merely tools for entertainment, drums evoke some pathos, influence behavior, and are tools of communication. According to him, drums are, indeed, rhetorical in most African contexts. 
persuasion goal notwithstanding, some scholars have criticized the notion of rhetoric as persuasion.

\subsection{Criticism of Rhetoric as Persuasion}

Although there are multiple ways of defining it, the notion of rhetoric as persuasion has been dominant in both classical and contemporary traditions of rhetorical studies. Aristotle's (2006) definition of rhetoric as “an ability, in each [particular] case, to see the available means of persuasion" (p. 37) has been significant in understandings of rhetoric, especially in civic discourse for persuasive purposes. Not all classical rhetorical theorists see rhetoric as persuasion, however; Quintilian, for example, considered rhetoric as the art of a good man speaking well, with his goals being justice, equality and truth. In our contemporary rhetorical times, too, a growing body of scholarship increasingly revisits this non-persuasion goal of rhetoric. Such notions are predicated on the view that to intend to persuade another person is to foist an opinion on them that is foreign to them. Rooted in anti-imperialist conceptions, these anti-persuasion orientations of rhetoric seek to present diverse points of view, with the aim of revealing or showing the beings of individuals. Invitational rhetoric, as Foss and Griffin (1995) define one such notion, is "an invitation to understanding as a means to create a relationship rooted in equality, immanent value, and selfdetermination. Invitational rhetoric constitutes an invitation to the audience to enter the rhetor's world and to see it as the rhetor does" (p. 5). It emphasizes the idea that in conversations, it is not merely enough to attempt to persuade others. In fact, the very 
idea of persuasion has embedded within it the understanding that one view is better and thus needs to be proffered to others who should then emulate it. The goal of invitational rhetoric, then, is not so much persuasion as it is an understanding of perspectives between interlocutors. Foss and Griffin (1995) point out that "[t]he act of changing others not only establishes the power of the rhetor over others but also devalues the lives and perspectives of those others" (p. 3). In rhetoric, a goal of change is probably rooted in what Foss and Griffin (1995) might have seen as the manipulative force of much rhetoric in which those with power and privilege seek to control those without them. Change, they suggest, is not the goal of an invitational approach to rhetoric; rather, it could be the result. While such an understanding of rhetoric allows that diverse views be explored in any communicative event, the SONA is not one of those communicative events. The primary goal of a president during this address is to look back on national performance within the year under review, and offer policy proposals to parliament or Congress for approval. Persuasion thus becomes an important goal without which a president's proposals to a legislative assembly of opposing political parties cannot be realized. A persuasive notion of rhetoric, then, is appropriate for both the genre of the SONA and an analysis such as this.

How do presidents persuade their audiences? In what ways are relations of power between presidents and their audiences negotiated? In the next section, I take up Critical Discourse Analysis (CDA) as a theoretical and methodological approach that 
concerns itself with power, in an attempt to demonstrate how presidents strategically negotiate power relations in the SONA.

\subsection{Critical Discourse Analysis/Studies}

Critical Discourse Analysis (CDA) (also called Critical Discourse Studies) has been an important analytical method since its inception in the early 1990s. It is rooted in a number of social theories of criticism, including the Critical Theory of the Frankfurt School which emphasizes critique of social and political structures as a necessary prerequisite for positive social change. CDA draws its attitude to criticism from its immediate antecedents, Critical Applied Linguistics, and Systemic Functional Linguistics, both of which recognize the role of language in the production and maintenance of unequal power structures. As an approach to text analysis, CDA scholars affirm the notion that the analysis of language use can reveal subtleties of power use and abuse in talk and text (see van Dijk, 1993; Fairclough 2013). More recently, Fairclough (2015) has reiterated the connection between language use and social practice through his three-step focus on critique, explanation and action. He argues that a critique of discourse precedes an explanation of the embeddedness of discourse within social practices and realities, and in turn allows for action geared towards change. Critiquing discourse is necessarily a critique of existing social realities since social realities, as Fairclough and most CDA scholars would agree, are constitutive of discourse. Fairclough recognizes the connection between critique, 
explanation and action as common to other forms of critical social science, but notes that it is CDA that has given it much prominence.

Although there have been a plethora of emphases and approaches to CDA, these have been united by common goals of "deconstructing ideologies and power through the systematic and retroductable investigation of semiotic data (written spoken or visual)" (Wodak \& Meyer, 2016, p. 4). Their common goals notwithstanding, Critical Discourse analysts focus on varying approaches to text analysis, recognizing that CDA is in itself "necessarily interdisciplinary and eclectic" (Wodak \& Meyer, 2016, p. 4). Such an eclectic approach enables analysts to select elements of analyses based on their own research questions, the genre of texts, as well as the kind of data that is to be analyzed.

Another key focus of CDA, notes Lin (2013), is its view of "language as social practice and particularly on the social and political context of language use" (p. 3). The importance of studying texts to uncover hidden ideologies and power is grounded in this notion. As Wodak and Meyer (2016) argue,

Discursive differences are negotiated in many texts. They are governed by differences in power that are in part encoded in and determined by discourse and genre. Therefore texts are often sites of struggle in that they show traces of differing discourses and ideologies contending and struggling for dominance. (p. 12) 
Hence, not only is it important that SONAs are analyzed to uncover power differentials, but it is especially critical to do so given that the focus in SONAs on the unity of the nation tends to be a desirable and often taken-for-granted ideal, and thus emphasized. This unity notwithstanding, there could be instances of subtle ideological differences that are masked by reference to this very same unity.

The emancipatory goals of CDA notwithstanding, some scholars have critiqued how practitioners use CDA. What follows is a brief discussion of some of these critiques.

\subsection{Criticisms against Critical Discourse Analysis/Studies}

Critical Discourse Analysis has been criticized for philosophical and methodological reasons, by scholars who use other approaches to text analysis. Particularly, practitioners of Conversation Analysis (CA) have been the most critical of CDA approaches. Schegloff (1997), for instance, pits Conversational Analysis (CA) against $\mathrm{CDA}$ with the claim that $\mathrm{CA}$ is empirically grounded, avoids overt political motivations that move the analysis towards certain predetermined goals, and focuses on the texts without political presuppositions. He advocates for a formalist approach that focuses on the text, without external considerations of any sort, as an initial attempt at arriving at the political goals of CDA. Further, he rejects the claim made by Critical Discourse analysts that it is important to approach an analysis by selecting salient contexts that make the analysis worthwhile. To Schegloff, such arbitrary selection makes the methodology of CDA unscientific, and thus unreliable, and raises the question of whose text and whose context is important. 
Schegloff's claim — and indeed that of CA in general— has been responded to by several analysts in the CDA tradition. Billig (1999), for example, has noted that CA is not ideologically neutral. The claim that CDA is politically motivated is as true of CA as it is of CDA. The analytic terms used by CA as well as the specialist terminologies employed by its analysts do not originate from the participants in a conversation, but rather are ideologically motivated and are assigned by those analysts. Billig argues, therefore, that the labelling of participants in CA is just as based on assumptions about what is useful for an analysis as when CDA explicitly identifies power as its goal. Billig posits, then, that there are probably more commonalities between the approaches than CA practitioners recognize.

Another critique of CDA is the notion that contrary to its professed emancipatory goals, the analyses do very little in terms of improving socio-economic conditions. In contrast to this claim, Fairclough (2015) argues that more than a critique of discourse, CDA aims to "analyze and criticize, and ultimately to change, the existing social reality in which such discourse is related in particular ways to other social elements such as power relations, ideologies, economic and political strategies and policies" (p. 5). His example about the nexus between the discourse of marketization of universities and neoliberal capitalism is an important case of how a politically oriented analytical method such as CDA can become significant in advocacy for change in social practices and systems. 
Finally, more recent criticisms of CDA have engaged gaps in CDA research, such as the neglect of the cognitive elements in discourse formation. Here, Chilton (2005), for example, has advocated for the inclusion of a cognitive dimension to CDA, since, according to him, it is mental schemas that determine how individuals first envision and then construct the world in talk and text. Further, Lazar's (2007) work has focused on feminist ideals in CDA research through her argument that feminism as a political cause is not accounted for in CDA research, although CDA, broadly construed, focuses on gender inequality as one of its political goals. Feminist CDA, as Lazar calls her approach, could fill the gaps not addressed by the study of gender in CDA, for gender, according to Lazar, is not necessarily feminist. Criticisms like Chilton's (2005) and Lazar's (2007) enable us to envision how an interdisciplinary approach could help fill some of the gaps identified in CDA research. A combination of approaches provides an impetus for the rhetorical (critical) discourse analysis used in this research project.

A CDA approach in this project will be essential in critiquing how power works in SONAs so that power relations can be better rethought. In this regard, I will discuss in the next section some linguistic strategies that are used to associate with and dissociate from audiences, as a segue into exploring the basis of power relations in discourse. I first take up and focus significantly on the first-person plural pronoun in English, "we." 


\subsection{Pronouns in Political Discourse}

The use of pronouns in political discourse has received some scholarly attention over the years. More than merely placeholders for nouns, pronouns are complex words that signal relationships between a speaker and an audience and are politically oriented towards the assignment of positions and the construct of representations of people (see Pennycook, 1994; Bramley, 2001; Scheibman, 2004). The personal pronouns "we" and "they" have especially been analyzed in political discourse as a means by which a corporate political "self" and "other" are constructed. Further, analysis of "we" is useful in uncovering the inclusivity and exclusivity of individuals in discourse since, even without the use of "they," "we" is one pronoun whose referent is often difficult to determine on the surface, and one that could be subtly used to exercise in-groupness and out-groupness. Helmbrecht (2002) indicates that the prototypical use of "we" is intended to create and reinforce group membership and social identity (p. 42). Since the referent of "we," unlike other pronouns, cannot readily be determined merely by looking at the pronoun, the discursive context becomes significant. Although there are several classifications of the uses of "we" such as the editorial "we" and the royal "we," this thesis focuses on inclusive "we" and exclusive "we": the former includes the addressee, while the latter excludes (some of) the addressees. Indeed, it is the historical loss of the dual number in English that conflates the functions of the inclusive and exclusive "we." The fact that "we" could be inclusive or exclusive also means that it could be "referentially ambiguous," with the goal that positive or negative face, as well as group membership, could be 
ensured (Scheibman, 2004, p. 381). Similar to Scheibman's argument is Duszak's (2002), where the latter had earlier argued that

Both we and they can be skillfully managed in discourse in order to construct, redistribute or change the social values of ingroupness and outgroupness. $W e$ in particular opens up a number of referential and pragmatic options (esp. [sic] the inclusive - exclusive distinction) and enjoys a strong cultural salience across languages and contexts. (p. 6)

"We," then, in and of itself, is neither inclusive nor exclusive; it is its use within particular contexts that determine its inclusivity or exclusivity. In her study of the use of "we" in the construction of British and Scottish national identities in newspapers, Petersoo (2007) found that "we" is an important pronominal choice in discourses about nationalism and national identities, noting further that in such discourses, it is not always that "we" is designed to mean "the nation" but it could be other things as well. In addition to the well-known inclusive-exclusive dichotomy, she introduces the concept of the wandering we, instances where there are contradictory uses of we, "usages that can be traced within a paragraph or a whole article" (p. 429). The instances of use of "we" could wander between variations of inclusiveness and exclusiveness, in a way that creates purposeful ambiguity aimed at political gain, for example. The analysis of "we" in discourses is also consistent with Íñigo-Mora’s (2004) argument that the first person plural pronoun "is the one most closely related to the concept of community" (p. 38). Thus, if the audience in both the Parliament of 
Ghana and the Congress of the United States could be regarded as a community in some sense, the analysis of the use of this pronoun in speeches to this audience could be an important pointer to how such community is constructed.

\subsection{Data Selection}

Data for the study consists of two addresses, one each by President Mahama and Obama. The speeches are the 2013 SONA of both presidents. I chose the speeches based on the scope of the research, specifically the limitations on length of this thesis. In that regard, I chose the first SONA by President Mahama, and President Obama's first during his second term as President. The speeches are transcripts of the video recordings of the addresses collected from the website of the Parliament of Ghana and the official White House webpage respectively. The transcripts were compared to the videos to ensure fidelity of the texts.

\subsection{Methodology}

I used an eclectic approach which draws on lexical elements from CDA research. First, I searched for all occurrences of "we" in the SONA, analyzing for instances of inclusive, exclusive, and where applicable, wandering "we." To establish some pattern and ensure consistency, I first analyzed SONAs delivered by both presidents from 2013 to 2016, focusing on all the uses of "we" and the expressive values of words within the same discursive environment as the "we" to determine the positive and negative associative meanings attached to the lexical items. Although "we" could 
be classified into several typologies, I focus only on inclusive and exclusive uses in order to establish how the presidents attempt to identify with the audiences and also dissociate from them. Given that I coded for inclusive and exclusive uses of "we," and also those uses that wander to create ambiguity, I then, for the purposes of this thesis, focused on the 2013 SONA of the presidents, and selected representative excerpts from all the instances in which inclusive and exclusive "we" are used. Also, because "we" is not in itself inclusive or exclusive, my knowledge of context—what Fairclough calls Members' Resources (MR) (2015, p. 155) — becomes significant in the analysis. I drew on my knowledge of the discursive context as well as the subject being discussed by the presidents to determine whether the uses are inclusive or exclusive. Where there appears to be ambiguity, I indicate how the uses of the "we's" could be seen as instances of wandering "we", and the likely purposes for such ambiguity. For ease of identification, lexical items that signal inclusion are underlined in the excerpts, while exclusive markers are in bold-face. The analyses are excerpts from the speeches, and follow the format, excerpt-paragraph-line. Where appropriate, and whether this influences our understanding of the excerpt, it is indicated whether the excerpt is from the introduction, body or conclusion of the speech. The grouping of the excerpts are done thematically, having been selected from paragraphs that are closely allied and which treat similar issues.

In focusing on the expressive values of the lexical items, I attempt to uncover instances where distinctions of association and dissociation are made between audiences. Fairclough (2015) notes that the expressive values of words, that is, those 
that assign negative or positive evaluations and associations to lexical items, are ideologically significant (p. 135-136). Thus, focusing on the lexical items used in the speeches could help establish the ideological values the speakers attach to the words. Finally, based on the occasions of rhetoric, I analyze situations where one type of rhetoric - epideictic or deliberative - correlates with a form of clusivity, as well as the significance of these. 


\section{CHAPTER THREE: ANALYZING STATE OF THE NATION ADDRESSES}

This chapter analyzes the speeches of both Presidents John Mahama and Barack Obama. The analysis focuses on the use of the different types of "we" identified in the previous chapter. I also analyze lexical items to show how these are used to exercise inclusivity and exclusivity. I first focus on inclusive and exclusive uses of "we." I also analyze selected lexical items to determine their expressive value, that is, larger issues they evoke. For the most part, the excerpts analyzed from the body paragraphs are a small sample of a larger whole. I searched for all occurrences of "we" in the essay before focusing on representative excerpts for the analysis. In each case, I demonstrate with examples from the speeches why the occurrence of "we" has to be considered as described, as well as the motivation behind the use of each type of "we."

\subsection{Analyzing President Mahama's SONA}

The following paragraphs constitute portions of the introduction of President John Mahama's 2013 SONA. In the following group of excerpts, notice how the lexical choices are meant to legitimize the position of the president and also celebrate common values and achievements of the Ghanaian people. To distinguish inclusivity and exclusivity, I underline lexical items that signal inclusivity, while those that express exclusivity in the text are bold-faced. It is indicated, also, where the excerpt leans towards wandering uses of "we." 


\section{Excerpt 1:}

(a) In particular, I wish to acknowledge our newest Members of Parliament and extend to all of them a warm welcome of partnership in shaping the destiny of our beloved country. As the elected President of this dear country, I wish to express my personal gratitude to all Ghanaians for the trust and confidence entrusted in me. I am fully conscious of the expectations of our people and I pledge to work with a sense of urgency and remain sincere and truthful at all times.

(b) Ghana is a different place now from what it was when we began the journey towards democratic governance. We have come a long way since 1993 when the first President of the 4th Republic, Jerry John Rawlings, delivered the first State of the Nation Address under the 4th Republican Constitution. Ghana's democratic credentials were further consolidated with the election of John Agyekum Kufuor and later Professor John Evans Atta Mills of blessed memory.

(c) Mr. Speaker, our recent Presidential and Parliamentary elections have been adjudged by both domestic and international observers as by far the most credible, transparent, free and fair since 1992. This shows that each 
step of our democratic journey has been marked by improvements. As Ghanaians, we must be proud of this achievement.

(d) Mr. Speaker, I believe that as a country we can achieve more by working together. Togetherness will enhance our capacity to meet our urgent needs; while promoting excellence and rewarding achievement. Ghana has witnessed impressive development in the last two decades. There have been improvements in roads and social infrastructure across the length and breadth of this country. Health facilities have been expanded and access improved, and so have educational institutions with the private sector playing a pivotal role. In many respects, Ghana has witnessed many positive changes for which we must all be proud.

(e) Mr. Speaker, this administration will pursue rapid economic development with a sense of urgency in order to create new jobs particularly for our youth. In partnership with the private sector, we will expand our infrastructure in a manner that will accelerate economic growth.

The use of "we" in Excerpt 1, paragraph (b), lines (1) and (2) is in tandem with the reference to "democratic credentials" that Ghana as a country has been able to attain. Drawing on a tradition of two decades that includes President John Agyekum Kufuor of the opposition New Patriotic Party (NPP) demonstrates the inclusivity that the 
reference to Ghana makes. The president suggests that Ghana's democratic credentials are not a preserve of any one political party, and are enviable, especially within the West-African sub-region.

It is worthy of note that the 2012 Presidential and Parliamentary elections in Ghana were heavily contested, culminating in a law suit filed at the Supreme Court of Ghana by the opposition New Patriotic Party (NPP), challenging the results of the election and the legitimacy of John Mahama as president. Any president in Ghana is necessarily an elected president. Thus, for the president to specifically state in his first SONA that "as the elected president of Ghana" demonstrates his intention to legitimate his presidential position against attacks from his political opponents.

Furthermore, the reference in Excerpt 1, paragraph (c) line (2) to the fact that the elections were adjudged by both "domestic and international observers" was intended to legitimize the president's position as a democratically elected president who derives his authority as head of state from the people. This line of reasoning provides a framework for us to understand the reference that follows in that same paragraph, that "[a]s Ghanaians, we must be proud of this achievement." The president thus draws on what could be said to be a common value of most Ghanaians - a preference for democracy —in order to establish that it is indeed "we" Ghanaians that must be proud of this achievement. One reason this inclusive "we" is used could be that having won an election whose results were still being contested at the law court, it was crucial for the president to be seen as a unifier of a nation on the verge of 
disarray. An inclusive "we" that identifies with the generality of Ghanaians, thus, enables the president to start his tenure on a note of consensus.

The president's reference in Excerpt 1 paragraph (d) line (2) to "togetherness" also alludes to the inclusive appeal that ensures the common values of all Ghanaians. In this case, he is not necessarily referring to opposing political parties in parliament but rather to the broad generality of Ghanaians. The emphasis on "Ghanaians" and "Ghana" in much of Excerpt 1 paragraph (d) helps to situate the use of "we" within an inclusive context. In one case, he refers to the achievement "Ghana" as a country has been able to attain. This puts the focus on the nation while deemphasizing the attention on himself and the political party he represents. In another instance in the same paragraph, the focus is again on "Ghana" and the many "positive changes" it has witnessed. There is then an inclusive "we" that calls for a celebration that "we all" must be proud. A celebration of the achievements of the nation Ghana enables the president not only to appeal to and include all Ghanaians but also to portray himself as representing the best interests of the whole nation. Especially for a president whose legitimacy was being challenged in court, such an inclusive "we" ensures that he is seen as a unifier.

Furthermore, Excerpt 1 paragraph (e) draws our attention toward the president's political party, and away from the nation. The use of "this administration" makes the use of "we" in the next sentence clearly exclusive of other political parties. While it might seem that such the president is only doing his constitutional duty of outlining policies of the executive to the legislature, the focus on the fact that his administration 
will do what has to be done enables us to see the use of "we" not through a national perspective, but rather as a partisan responsibility to be performed by the ruling government. This is especially critical when we consider the fact that although the SONA is, in essence, a national report, competing interests, and politics - in the sense of who gets what, when and how_are always at play. The use of an exclusive "we" here is probably to enhance a positive image of the government as one focused on delivering on its electoral promises in an election that had just ended. The use of exclusive "we" in the paragraph above provides a basis for our understanding of other uses of the deictic pronoun.

In the next group of excerpts, I identify the president's frequent focus on term limits and his position as president, both of which are geared towards enhancing a positive image for him and his party. Notice, too, the shift to sports as a cherished value of the Ghanaian people. Inclusivity is again marked here through bold-faced, underlined words, while exclusivity is simply bold-faced. Note the transition to more exclusivity.

\section{Excerpt 2:}

(a) Over the next four years, we will build an economy that rewards hard work and nurtures Ghanaian entrepreneurs and businesses whose prospects will not be tied to political cycles and patronage. As President, I am firmly focused on these goals, because these are the right things to do. 
(b) Mr. Speaker, in my first term as President, I will focus on delivering on the following, which constitute the vital pillars underpinning our national development programme. 1. Putting the People First 2. A Strong and Resilient Economy 3. Expanding Infrastructure 4. Transparent and Accountable Governance.

(c) Mr. Speaker, as a Social Democratic Party, we put people first. We believe that our people are our most treasured asset and this is what informs our social development agenda. The thrust of our social policy and human development programme revolves around education, healthcare, social security and protection for the vulnerable- women, children, the aged and people with disabilities. We will focus on and emphasize the productive and reproductive capabilities of these social groupings, while ensuring at the same time that the most vulnerable in our society are effectively protected.

(d) The Ministry will establish a database of the poorest households or individuals in our society and fashion programmes to enhance their access to social services. This Ministry is at the heart of our being as social democrats. The fruits of economic shall be equitably shared for the benefit of our population. We cannot advance as a nation, half poor and half rich. Our Minister assigned to GCSP [Gender, Children and Social 
Protection] is experienced and capable and I am sure that many will soon see the results of her expertise in that sector.

(e) Mr. Speaker, let me now turn my attention to an area that has often proven to be one of the greatest unifiers of our people, sports. A few weeks ago, we had to endure the painful experience of missing out on our muchcherished dream of winning a fifth African Cup of Nations title.

Still expanding on the proposals of the executive branch of government, the president begins to explain at the beginning of Excerpt 2 (a) his plans for "the next four years" in the main body of the speech. Given that the Ghanaian constitutional mandate does not specify a "national year" within which the activities of the preceding year have to be accounted for, the reference to a four-year term becomes significant here as it points to the four-year presidential term in Ghana. The reference to the year limit seems to suggest that the president's policies are circumscribed by his tenure in office. It is widely known in Ghana that successive governments, even since independence, have often discontinued developmental projects begun by previous governments, particularly when there is a party change, probably as not to lend credence to the ideas and policies of those parties. In this light, it becomes obvious why such references in the SONA that limit policies to presidential terms could be seen as an action that is exclusionary of opposing political parties. The reference to the four-year term also further enhances our understanding that the "we" who will build the economy is the political party to which the president belongs and not 
necessarily what the nation as a whole would do. Exclusivity thus becomes a tool towards positive image presentation for the president's political party, the National Democratic Congress (NDC). Notice in Excerpt 2 (c) and (d) the use of "will" which suggests a tense change to the future about what will be done. Such usages constitutes goal statements. While not directly related to inclusivity nor exclusivity, such tense markers serve to indicate instances where the president outline policy proposals.

The focus on the term limit in Excerpt 2 (a) is further reinforced in Excerpt 2 (b) that follows, where the president refers to what he will do in his first term of office, with our attention drawn to himself. The use of "our national development programme" suggests a common goal towards which Ghana as a nation works. The tone thus appears to shift the focus away from the president and his political party temporarily to the generality of Ghanaians. This focus on the president, however, gives way, one more time, to a focus on the incumbent political party in Excerpt 2 (c) which directly followed 2 (b) in the speech. Here, the president conflates the "national development programme" and "our social development agenda" as though both were one. "As a Social Democratic Party" in Excerpt 2 (c) is a subtle reference to the president's own party, the National Democratic Congress (NDC). From this point on in the paragraph, we see that all references to "we" are exclusively about the NDC. It becomes clear that the "national development programme" is not different from the "social development agenda," hence the exclusivity of opposition political parties. Bipartisanship is not stressed since the focus is not so much on what is to be done or 
is being done as a nation, but rather on what the incumbent political party has done and will do. This is where the exclusivity is exercised.

Furthermore, Excerpt 2 (d) enables us to establish a connection between the incumbent government and the Ministry for Gender, Children and Social Protection. The president announces the establishment of this new ministry and states further that its mandate is at the heart of "our being as social democrats," clearly a reference to his political party. This focus on the NDC gives way in the next sentence to a critique of what it is morally wrong to do as a nation. The use of "we" and "nation" in "We cannot advance as a nation..." portrays the call for equity as a collective duty that everyone must work towards, by virtue of their being Ghanaians, and regardless of their political affiliation. It becomes clear here that when it is a question of morality about which very little dissension may be expected, there is an appeal to inclusivity, and hence the use of the inclusive "we" above; however, on matters of power differentials such as those that give credit to one political party instead of another, exclusivity is used.

We see a shift back to inclusive language again in the reference to sports. As noted in Excerpt 1 (d) above, sports is a major unifier of the Ghanaian people. Since the issue of loss of a football game is collective, and not one over which there would be much contention, the president draws on this knowledge to be inclusive. In Excerpt 2 (e) lines (2) and (3), the use of "we" in "We had to endure the painful experience," and "unifiers of our people" thus refer to the Ghanaian people in general and not any one political party. 
From the analysis of this second group of excerpts, it could be argued that exclusivity is aimed at positive self-presentation (of the president and his political party); inclusivity is used when there is very little about which people could debate, such as common values and morals, and shared experiences. Further, while it is the entire nation that is referred to in instances of the use of inclusive language, it is opposing political parties that seem to be the target of exclusionary language. This again strengthens the argument that the goal of exclusivity is political gain.

What follows in the next group of excerpts is a celebration of national achievements through references to the nation Ghana and its place among the comity of nations.

\section{Excerpt 3:}

(a) Mr. Speaker, Ghana continues to exhibit strong leadership in democratic governance, which makes us the envy of many nations. As noted earlier, we have just come out of an historic election which witnessed progressive reforms including the use of a biometric voters register and biometric verification for voting which has been acclaimed by both domestic and international observers as free, fair and transparent.

(b) Mr. Speaker, our commitment to peace and security in the West African Region is paramount in our foreign policy considerations. We have recently joined with ECOWAS [The Economic Community of West African States] in seeking a permanent resolution of the conflict in Mali, by contributing a 
modest detachment of our armed forces to participate in the African-led force operating in Mali, AFISMA.

(c) As the actual armed conflict is abating, Ghana stands ready to use our rich

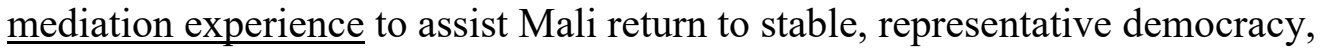
just as we have done in times past in helping bring peace to Liberia. Sierra Leone and Cote d'Ivoire.

(d) Under my Presidency, Ghanaians and the international community can trust that Ghana will uphold all its commitments to the UN, the AU, the Commonwealth, ECOWAS and other international organizations to which we belong.

As noted in the analyses in the last group of excerpts, inclusivity is used when there is no contention over what is being discussed. In Excerpt 3 (a) above, the President makes reference to Ghana's position as an example of democracy to most countries in Africa. Like the reference in Excerpt 3 (b) to Ghana's peacekeeping efforts and deployment of "armed forces," these do not necessarily seem to be made in praise of either the president or his political party. In all the excerpts above, the focus is on Ghana as a country and what it has come to be known for. Thus, it could be said that the president draws on these achievements and values to which he may not legitimately lay claim, for purposes of political gain, since this is a question of reflected glory, which the Ghanaian people have collectively entrusted to him as 
president. Like moral issues and values, these achievements are common to all Ghanaians, so it becomes significant that the president uses these as inclusive language. Also significant is the reference to the "international community" who may be listening to the president's speech with expectations that their strategic interestsin diplomacy, trade, international relations, among others—will be satisfied.

Finally, when we consider Excerpt 3 (a), we realize how exclusive language is used to justify and legitimize the president's position as head of state. Considering that the results of the 2012 Presidential and Parliamentary Elections were being contested in court, internally acknowledging the views of "both domestic and international observers" on the transparency of the elections was one way of the president affirms that he is the rightfully elected head of state. Since the most important political issue between political parties especially during a national electioneering periods is a claim to the presidency, political parties would go any length to assert their actions. It is thus not surprising that the president uses the occasion of the SONA as an occasion for positive self-presentation and legitimation. Also, although of secondary importance, the use of "Under my presidency" in Excerpt 3 (d) line (1) foregrounds the agency of the president by investing in him an authority that becomes a selfpromotional tool.

The excerpts below are significant in the ways they reiterate some common achievements of the Ghanaian people while using religion, a cohesive force in traditional Ghanaian society toward manipulative ways. 


\section{Excerpt 4:}

(a) I reaffirm my commitment to uniting Ghanaians as one people. We are a nation of diverse cultures and religious beliefs; there is a tremendous amount of beauty in our diversity. While we celebrate our diversity, let us explore what unites us instead of focusing on the things that divide us.

(b) Mr. Speaker, we are determined to deliver on the development goals, which I have outlined. We have objectives to meet and the expectations of our society to fulfill; our people expect to see results, whether it is in the delivery of water, electricity, healthcare or sanitation services. We must not overlook the little things that matter to our people even as we stress on responsible citizenship as an important factor in nation-building.

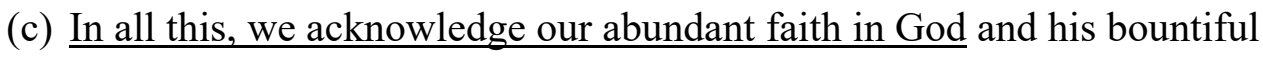
mercies on our nation. God's divine favour is on Ghana. We have no cause to fear. With God in our boat we will smile at the storm. I know we will not fail our country and I know God will not fail us either. God bless Ghana. ${ }^{5}$

\footnotetext{
${ }^{5}$ While this is the only instance in the entire speech where reference to God and religion is made, it is nonetheless a highly significant point to draw attention to, considering the place of religion in the worldview of most African cultures. Besides, such references to God and religion run through other SONA not only by this president but by other past Ghanaian presidents as well. These have not been included in the analysis as they fall outside the scope of this research.
} 
The president uses the concluding section of the speech to reiterate some of the proposals he had earlier announced, while summarizing his policy recommendations. Although the call for the unity of Ghanaians suggests inclusivity, it is only so, insofar as it does not constitute a struggle over power. Since the call for unity of Ghana's diverse religious and cultural groupings is morally desirable, the president affirms this ideal in an inclusive way. Inclusivity, then, could again be seen as an assertion of common values over which political parties might offer very little resistance, if any at all.

In Excerpt 4 (b) the use of "we" works together with "I" to show that the president and the NDC are the focus of the sentence. There is no indication that the "we" refers to other political parties or Ghanaians in general, since the proposals outlined by the president do not exhibit any signs of reference to the other party or their accomplishments. At the same time, the use of "we" here could very well be an ambiguous use of the pronoun. "We are determined to deliver" could refer also to what Ghanaians as a whole could and must do to meet the development goals of the nation. In this case then, such ambiguous, wandering uses of "we" have the effect of potentially appealing to the wider Ghanaian audiences. Because it is not absolutely clear who is meant here - the president's party or the Ghanaian people--, the wandering "we" here becomes a rhetorical useful way of communicating the president's idea. Again, one important factor in determining the exclusivity of most of these examples is that not only are alternative perspectives not demonstrated but there is hardly any reference to bipartisanship in terms of what the two major political 
parties in Ghana's parliament, the opposition New Patriotic Party (NPP) and the incumbent (NDC), could cooperate on for national development. The absence of a call for bipartisanship promotes divisive viewpoints on major policy issues and further cements the position of political parties as ideologically different groups working at cross-purposes.

Most important of all in the above excerpts is the president's reference to God. As the last paragraph of the president's speech, Excerpt 4 (d) is the culmination of all his plans. It is significant in that he appears to entrust his plans to the providence of God. Although the president indicates that "we will not fail our country," he adds also that "God will not fail us either." It is no longer the case that his government must strive towards attaining the goals he has outlined in the speech but rather that Ghanaians have no cause to fear since the achievement of his plans is in God's hands. He envisages challenges, based on which he announces that "we," that is, Ghanaians have nothing to fear since God is in control. As God's blessed and protected nation, Ghana has no cause to fear; it will overcome difficulties by God's help. Such a reference to God is different from the common formulaic expression "God bless you" or "God bless Ghana." "In all this" suggests that the attainment of all the plans outlined greatly depends on God's blessings, perhaps without which they might not be attained. This confidence in the overwhelming power of religion seems to suggest that Ghanaians can place their faith in Mahama in advance because God has already blessed Ghana. Arguably, then, solutions to challenges are, therefore, preordained, and individual innovation and a striving to attain the goals set in the speech become 
deemphasized. This way, the president is partly, if not entirely, absolved from any failure to achieve his set goals. The president is confident that he will not fail Ghanaians, and neither would God. However, implicit in this sentence is the idea that success is possible to the extent that God does not fail Ghanaians, too. The president relies on commonly held idea that most Africans (and Ghanaians for that matter) acknowledge the influence of the divine in the affairs of men. He uses this knowledge towards a rhetorical advantage.

Religion plays a dominant part in many African worldviews. In his study of Ancient African rhetorical practices, Campbell (2006) found that religion was a critical part of a rhetor's persuasive arsenal. Referring to a speaker's ethos, he explains that

Appeals to divine ethos may have been a common feature of royal discourse at this time, which could lend credence to Kennedy's claim that in traditional societies "the primary means of persuasion is the authority or ethos of the speaker.” (p. 261)

While his study focused on ancient civilizations of Nubia, Axum and Mali, Campbell draws a connection between rhetorical strategies in such ancient civilizations and those of African societies not heavily influenced by cultures of the West. Although Ghana's contact with the West has had a substantial influence on much of its culture, the traditional influence of religion continues to be felt in public life. Dovlo's (2004) work on religion and politics in Ghana chronicles the influence of religion, especially Christianity, on the Ghanaian political sphere, from Ghana's first president Kwame 
Nkrumah to the early days of this century. Significantly, he argues that the roles of traditional leadership in most African countries involve religious functions which are often carried into the modern political arena (Dovlo, 2004, p. 201). Thus, President John Mahama's invocation of religion above can be understood within the context of the Ghanaian (and African) worldview of the place of religion in politics. While Ghanaian presidents since independence have often relied on and extended the influences of religion within traditional Ghanaian settings to modern-day politics, President John Mahama's use of religious imagery could be seen as an offshoot of his particular positions as first, Vice-President, and then President of Ghana. On July 24, 2012, Ghana’s President John Evans Atta Mills died, six months to Ghana’s Presidential and Parliamentary Elections that year. President Mills had been known for his religious posture in governance, with frequent calls on Ghanaians to place their trust in God to direct the country towards prosperity. Famously, references to the Ghanaian public in his public speeches as "My brothers and sisters," and several such addresses with religious connotations worked together to create an image of him as a God-fearing, religious man whose politics were built on faith in God, and specifically, his Christian principles. Of particular interest during his presidency was his relationship with religious organizations. Once, in a courtesy call on him by the Ghana Pentecostal Council (the umbrella organization for all Christian Pentecostal groups in Ghana) at the Castle, the president was reported as saying that "Such Men of God are allies who can support the success of my administration and the progress 
of the nation through their intercession" "6 (GhanaWeb, 2013). Thus, it is within this religious context that Vice President Mahama continues President Mills' legacy, first as flagbearer of the National Democratic Congress (NDC) in the run-up to the 2012 elections, and later as president of Ghana since 2012. Indeed as Dovlo's research concludes on the nexus between religion and politics in Ghana,

Religion and Politics in Ghana are often yoked in a partnership that belies the supposed secular status of the State. Generally, it appears that politicians use religion in an exploitative way due to the perceived influence it wields [emphasis added] on the electorate, in order to attract an entire group without reaching out to them individually $[\ldots] .(2004$, p. 217)

Clearly, "God," as President Mahama uses it, might refer to the Christian God (given that he is himself a Christian), but associative meaning of the word with anything divine could appeal to Ghanaians of diverse religious affiliations, be they Christians, Muslims, African Traditionalists or Buddhists, even though such groups have specific names for the a supreme being. The use of the "God", therefore, potentially appeals to an entire group, as Dovlo notes, and not necessarily to specific individuals. It is within such collectivity that religion becomes a cohesive, but also manipulative tool in the hands of politicians.

${ }^{6}$ Prior to this meeting, President Mills had proposed, at the beginning of his tenure as president, a National Muslims and Christians Day of Prayers and Thanksgiving to forge unity. (See https://www.modernghana.com/news/201059/national-thanksgivingservice-held.html ). It is to be noted that while Christianity and Islam are the two major religions in Ghana, other religions exist as well. 


\subsubsection{Summary of Analysis of President Mahama's SONA}

The foregoing analysis of President Mahama's speech reveals a number of interesting insights. First, the genre of the address itself calls for a speech that is non-adversarial, unlike an election campaign speech, for example. Second, the president uses inclusive language (through lexical choices and inclusive "we's") when he intends to associate with the general Ghanaian public and opposition political parties. Such association is made only in situations where there is little or no dissent at all. e.g. on values, morality, and collective Ghanaian achievements that transcend the tenure of a single political party. The president never invokes opposition political parties but instead uses indirection to call them out. Why this is so might be explained by the function of indirection in Akan discourse, and by extension, traditional Ghanaian society. In his discussion of aspects of Akan persuasive language, Agyekum (2004), drawing on Goffman's concept of face, suggests that Akan society (like many African societies) is communalistic and sees the concept of face as "a public (rather than personal property) on loan from the society" (p. 68). The goal of indirection in interactions, he insists, is to avoid conflict and establish a social, affective relationship with one's audience/interlocutor. His arguments corroborate earlier research that indirection is used in political discourse to gain political and interactional advantage over one's opponents, while preserving social cohesion and warding off face-threatening acts (Yankah, 1991; Obeng, 1997). Indeed, given the transference of traditional Ghanaian cultural and societal norms and expectations of interaction and formal speech into modern institutions (Yankah, 1998), we could assume that the president's use of 
indirection is geared towards avoiding direct confrontation and name-calling of his political opponents.

\subsection{Analyzing President Obama's SONA}

I now turn to an analysis of President Obama's 2013 SONA. As done above, I isolate excerpts, focusing on linguistic elements that are used to exercise inclusivity and exclusivity. Notice, especially in Excerpt 5, the calls for bipartisanship that are subtle references to the obstructionism of the president's political opponents. These excerpts are taken from the introductory paragraphs of the speech.

\section{Excerpt 5:}

(a) So, together, we have cleared away the rubble of crisis, and we can say with renewed confidence that the State of the Union is stronger.

(b) It is our unfinished task to make sure that this government works on behalf of the many, and not the few.

(c) The American people don't expect government to solve every problem. They don't expect those of us in this chamber to agree on every issue. But they expect us to put the nation's interests before party. They do expect us to forge reasonable compromise where we can. For they know that America moves 
forward when we do so together, and that the responsibility of improving this union remains the task of us all.

One of the ways in which inclusivity is ensured is through the reference to the collective efforts of Americans. In Excerpt 5 (a) (1), the president makes the claim that "together," we - that is, Americans - have significantly reduced the negative effects of the economic crisis that hit the world in 2008. There is an all-encompassing tone to the claim with the focus on the nation. "We" here is used in terms of its inclusivity.

Excerpt 5 (b) is a shift from this inclusivity to some form of exclusivity. While "our unfinished task" might appear to be collective of all Americans, it is actually a criticism of the opposition party, Republicans, in Congress. "This government" working on behalf of all people means that there are some whose actions prevent such a goal from being realized. The Republican Party has largely obstructed President Obama's policies in Congress, as they constitute the majority of Congressional members, especially during the period leading up to this speech. "This government" refers to both parties, and yet President Obama uses it to call out Republicans. Since the SONA is televised to the larger American public, it has become an opportunity for an American president to speak above the heads of members of Congress to reach the populace, thus rallying their support behind the president's policies. The president's tone is thus not necessarily inclusive but rather as a way of calling out the other party indirectly, in front of all Americans, as it were. 
Excerpt 5 (c) reinforces the dichotomy created between the opposing parties, as could be seen in the excerpt before it. Again, relying on the American people's expectations of its leaders, the president calls for bipartisanship in support of his policies. Calling for the setting aside of party politics means he recognizes that there are some people who do not support his policies. One aim for this call for bipartisanship could be that since the president is able to talk to the general American public beyond his primary, immediate audience of members of Congress, he is able to court public support that improves his image and his party's.

The next group of excerpts further strengthens the idea that the president uses the SONA as a positive self-presentation and negative other-presentation. Notice also how one audience is used as a catalyst in persuading another.

\section{Excerpt 6:}

(a) These sudden, harsh, arbitrary cuts would jeopardize our military readiness. They'd devastate priorities like education, and energy, and medical research. They would certainly slow our recovery, and cost us hundreds of thousands of jobs. That's why Democrats, Republicans, business leaders, and economists have already said that these cuts, known here in Washington as the sequester, are a really bad idea. 
(b) Now, some in Congress have proposed preventing only the defense cuts by making even bigger cuts to things like education and job training, Medicare and Social Security benefits. That idea is even worse.

(c) And those of us who care deeply about programs like Medicare must embrace the need for modest reforms - otherwise, our retirement programs will crowd out the investments we need for our children, and jeopardize the promise of a secure retirement for future generations.

The excerpts above demonstrate the ways in which the president uses one audience (the American people) as an appeal to another (members of Congress) in achieving his policy recommendations. There is a focus on what is collectively beneficial to the American people: military readiness, research and jobs. Regardless of one's political affiliation, the security of the American people is hardly a contestable issue, but how to achieve it is. Since this is a matter over which there could be much disagreement on approach, the president becomes inclusive in his language, appealing to what is good for all Americans. The reference to both political parties as well as major stakeholders forces us to consider the inclusivity of the president's language. Not only is he then trying to convince all political parties but saying that "business leaders" and "economists" reject the idea makes it a strong point to convince all Americans that it is unreasonable to continue with such budget cuts.

Excerpt 6 (b) stands in direct contrast to the inclusivity in the paragraph before. It is an indirect reference to his opposing political party members who often obstruct the 
realization of his policies. "Some in Congress" refers to members of the Republican Party who have opposed a number of the president's policies over time, including his policies of Medicare and Social Security benefits as have been mentioned. Such an indirect reference enables the president to exclude the opposition party without appearing to have done so or without saying their name. It is this same exclusivity that is relied on in "those of us who care deeply about program" as to suggest that there are some people across party lines who care "deeply" about helping Americans and others who do not. Obviously, it is members of the president's party who are likely to be on his side and who care about his policies. Ultimately, the president excludes the opposition party by dissociating from their apparent sabotage. He also hems them in when he appeals to their sense of responsibility towards the "investments we need for our children." There is thus an inclusive use of this latter "we" which suggests that it is everyone's responsibility, irrespective of their political affiliation.

Also critical to the understanding of President Obama's expression of inclusive and exclusive strategies is the use of the ideal of the hardworking American to convince Congress members. In the excerpts that follow, consider how the president rhetorically questions the alternatives offered by the opposition as a way of dissociating from their plans that may not work. 


\section{Excerpt 7:}

(a) After all, why would we choose to make deeper cuts to education and Medicare just to protect special interest tax breaks? How is that fair? Why is it that deficit reduction is a big emergency justifying making cuts in Social Security benefits but not closing some loopholes? How does that promote growth?

(b) So let's set party interests aside and work to pass a budget that replaces reckless cuts with smart savings and wise investments in our future. And let's do it without the brinksmanship that stresses consumers and scares off investors.

(c) Let's agree right here, right now to keep the people's government open, and pay our bills on time, and always uphold the full faith and credit of the United

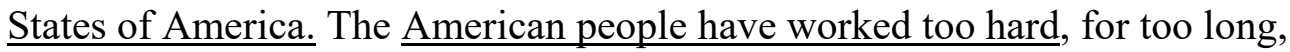
rebuilding from one crisis to see their elected officials cause another.

(d) After years of talking about it, we're finally poised to control our own energy future. We produce more oil at home than we have in 15 years. We have doubled the distance our cars will go on a gallon of gas, and the amount of renewable energy we generate from sources like wind and solar-with tens of thousands of good American jobs to show for it. 
(e) We can choose to believe that Superstorm Sandy, and the most severe droughts in decades, and the worst wildfires some states have are ever seen were all just a freak coincidence. Or we can choose to believe in the overwhelming judgment of science - and act before it is too late.

Cuts to the federal budget have been a wedge issue between Democrats and Republicans, especially during the presidency of Obama. Embedded in the series of rhetorical questions the president asks in Excerpt 7 (a) is the assumption that the course of action being taken by others is misplaced. Coupled with "after all," in Excerpt 7 (a) line (1), we can deduce that the use of "we" in "why would we..." actually stands for the Republican Party since the president's party could not be seen to be the ones who are taking an action that he in turn criticizes. Also embodying a criticism of Republicans are all the other series of questions in that same excerpt. Since these are issues over which both parties are not in agreement, we can clearly see the use of "exclusive we" here. It is not Democratic members of Congress being referred to here. It is rather Republicans. In Excerpt 7 (e), rather than critique Republicans directly, the president uses several strategic and odd "we's" in "We can choose to believe that Superstorm Sandy..." and "[W]e can choose to believe in the overwhelming judgment of science...," for example, to mitigate direct face-threats through the modelling of consensus.

The call for bipartisanship in Excerpt 7 (b) reflects the divergent posture of both parties on the proposals the president discusses. He calls for a rejection of a partisan approach in favor of a bipartisan approach to national issues. Not only are there calls 
for bipartisanship; the audience is encouraged to join the president's side to reject obstructionist tendencies that Republicans have been noted for during much of President Obama's tenure. These calls are reflected in lexical choices such as "keeping the people's government open," which is an indirect reference to the threat of shutdown of government business as a result of the inability of both political parties to agree on budget proposals. By saying "let's do it without the brinksmanship" Obama is engaging in a form of dog-whistle politics by subtly criticizing the Republican Senator Ted Cruz and members of the Tea Party who would rather advocate for a government shutdown than agree to a compromise on budget cuts. Beneath the veneer of inclusivity that the use of "let's" affords lies also a calling out of political opponents. The ambiguity of using "let's" (where "you" could have been used, for instance) enables the president to call out his Republican opponents who engage in brinksmanship without actually referring to them by name. Again, since he is able to address the larger American public, the president frequently appeals in an inclusive manner to their innovative drive and spirit of hard work, based on which members of Congress are called upon not to jeopardize the American people's path to success through their own actions.

Establishing an inclusive tone could also be seen in examples that encompass the efforts of all. The use of "we" in Excerpt (d) is inclusive in that it is all Americans that whose "own energy future" is being talked about. The speaker appears to have adopted an inclusive tone in talking about America's production of oil at levels not seen before, and it is the same tone that presents the generation of electricity. In these 
cases, it is the American people as a whole whose efforts seem to be referred to, as there is no direct reference that it is one party rather than another that deserves praise for these.

The inclusive tone notwithstanding, the president's tone shifts, one more time, towards a criticism of his opponent's opinions on issues. Here too, in the final except, 7 (d) above, "we" assumes an exclusive tone, as it calls out Republicans for their views on the issue of climate change. Republicans and Democrats have divided opinions on climate change, thus when the president says in Excerpt 7 (e) line (1) that "we can choose to believe" in reference to the hurricane Superstorm Sandy, he is referring to Republicans, most of whom claim not to believe that human-caused climate change is the cause of most of these disasters. "We" here then means "you" Republicans and not " $u s$ " Democrats. The fact that two options are presented here, one on believing in "just a freak coincidence" and the other in assenting to "the overwhelming judgment of science" lends credence to the argument that it is two fundamentally different positions that are being considered. The former, to which Republicans seem to lend their support, may not be credible since it based on chance, with no reliability; the latter, the Democratic position, appears to be the more credible option. It is based on a reliable method—science — and should be believed. Ultimately, it is Republicans whom the president calls out and dissociates from. In this final group of excerpts from the conclusion of the speech to which I turn, I demonstrate how the paragraphs excerpted establish the values of the American 
people and become the means by which an inclusive tone is adopted to appeal to all Americans.

\section{Excerpt 8:}

(a) [A]nd that well into our third century as a nation, it remains the task of us all, as citizens of these United States, to be the authors of the next great chapter of our American story.

(b) That's just the way we are made. We may do different jobs and wear different uniforms, and hold different views than the person beside us. But as Americans, we all share the same proud title - we are citizens. It's a word that doesn't just describe our nationality or legal status. It describes the way we are made.

In concluding the speech, the president adopts an inclusive strategy that appeals to all Americans. He challenges the nation to be the authors, not of a success story of his party, for example, but of "our American story". The task is collective, being for "us all", "as a nation." As the final remarks to his list of proposals, the president draws on values that unite all Americans: their citizenship. The "we's" used in Excerpt 8 (b) all point to Americans and not any single political party. The goal here is to be inclusive of everybody. Lexical choices such as "as Americans" further foreground the nation. The shift from the political party to the nation in these concluding moments of the speech appears to be to a move towards emphasizing the commonality that all Americans share as citizens and because of which they must work in the interest of 
all. In contrast, the president exercises inclusivity when he wants to rally the public in support of policies that seem to be obstructed by opposition party in Congress.

\subsubsection{Summary of Analysis of President Obama's SONA}

In general, President Obama appeals to the American people through references their common values of hard work, and glorious achievements. He draws on the expectations that the American people have of their representatives in order to convince Congress members to work in a bipartisan manner. He suggests that such bipartisanships are will better serve the American people. By so doing, he shifts the focus away from himself to the nation. Nevertheless, on policies that have previously seen much disagreement, and where he anticipates obstructionism on the part of his political opponents, he obliquely criticizing them. Inclusivity and exclusivity are thus used to achieve his epideictic goals of uniting the nation, and his deliberative aims of setting agenda and policies.

In the next section, I focus on some socio-cultural expectations that affect communication in contemporary Ghanaian society.

\subsection{Cultural Impacts on Contemporary Ghanaian Communication}

The foregoing analyses, especially of the Ghanaian text, raises a number of questions about the socio-cultural foundations, norms and expectations of communication. To what extent, for instance, does Ghana's unique situation as a postcolonial nation affect the ways in which borrowed rhetorical genres and practices such as the SONA are negotiated? 
In a $21^{\text {st }}$ century presidential speech in Ghana, finding an authentically Ghanaian norm of communication is nearly impossible because of Ghana's postcolonial situation in which precolonial structures in practically every area of life have been supplanted by colonial structures. In his study on the cultural foundations of communication in contemporary Ghana, Yankah suggests that Ghana's long contact with the West has brought about a tension between traditional norms of communication, such as avoidance of face-threats, and Western norms of communication in an age of electronic and print media. According to Yankah, the tension between tradition and modernity in terms of communication presents a dilemma for a postcolonial African nation:

Not only does one have to reckon with a foreign language which comes with its own norms of usage; there are also new channels of communication, print journalism, radio, television, telephone, electronic communication, internet, etc., where the face factor intrinsic in indigenous communication is eliminated. The modern nation state is thus confronted with competing norms, and faces a choice between the wholesale adoption of modern institutions and media with all their associated norms, and operating foreign institutions within a cultural frame of reference. ${ }^{7}$ (1998, p. 29)

${ }^{7}$ It is important to note that much of Yankah's work has focused primarily on elements of Ghanaian communication that might not be considered rhetorical within Euro-American contexts. e.g. the rhetorical nature of proverbs (Yankah, 2012), and elements of formal royal speech in traditional Ghanaian society (Yankah, 1995). While these studies have dealt mostly with traditional communication, some of the 
Not only has Ghana adopted the modern institution of Parliament with its SONA. Portions of the address itself could be understood within remnants of the cultural frame of reference associated with traditional communication in Ghana, one of which is the role of religion. At the very least, a recovery of traditional norms of communication (especially as it applies to the SONA) could be encouraged, since as Yankah further notes, "[t]he linguistic legacy bequeathed to us [Ghanaians] by the forces of modernity, in itself does not facilitate compliance with indigenous norms of communication" (1998, p. 40).

Furthermore, the length of the Ghanaian SONA analyzed often range between two and three hours (approximately 60 pages of written text); this could be a result of the transference of mediated communication practices from traditional Ghanaian society to contemporary postcolonial times ${ }^{8}$. Indeed, in Speaking for the Chief, Yankah (1995) discusses the circuit of formal talk in traditional Akan society, in which royal speech in formal speaking situations are routed through a chief's intermediary. The goal here is to embellish the speech through "indirection, ambiguity and circumlocution", for "[r] outing speech through another," in the Akan (and largely Ghanaian) scheme of things, "creates opportunities for a dull message to be given a new lease of energy, through stylized manipulation of the code" (Yankah, 1995, p.

arguments are still relevant for understanding this research work, as it fits with Mao's discussion raised earlier.

${ }^{8}$ It is often very common to have very lengthy addresses during state and other official functions in Ghana, even when shorter addresses will suffice. This is the background that informs this argument. 
107). Given that some traditional norms of communication have been carried over into contemporary Ghanaian political sphere, it is possible that the very lengthy formal speeches such as the SONA in Ghana resonate with the flowery and lengthy speeches of the chief's court. Such long speeches serve to shed more light on how traditional norms possibly impact contemporary communication practices.

In the final chapter, I conclude with insights on how the analysis in Chapter 4 could enable us to re-envision power especially in non-Western contexts. 


\section{CHAPTER FOUR: RE-ENVISIONING RHETORIC AND CDA IN AFRICAN CONTEXTS}

\subsection{Summary}

This thesis has examined the ways in which association and dissociation are exercised in presidential rhetoric. Focusing on a selection of SONAs in Ghana and the United States, I argue that a president's unique position as head of government and head of state during such an address presents a dilemma: party interests conflict with national interests, with the result that the president dissociates from his political opponents when the issue at stake has political advantage for the incumbent government.

This analysis investigated clusivity in the speeches, as well the expressive values of lexical items. The expressive values analyzed revealed the positive associations —of continental leadership, national achievement, and call to bipartisanship—but also negative connotations of political party achievement only, at the expense of national achievement. Also, the study explored the interdisciplinary research approach of rhetorical discourse analysis (RDA). With RDA, the analysis relied on two of Aristotle's three occasions of rhetoric - deliberative and epideictic rhetoric. Critical Discourse Analysis focused on the deictic elements (specifically the use of inclusive, exclusive, and wandering "we"), and lexical items that demonstrate the expressive value of words and show power differentials. The use of both approaches in an interdisciplinary manner reveals how linguistic analysis (in the form of CDA) and rhetoric can enrich each other. For example, it could be seen in the analyses that in 
cases where both presidents associate with their audiences (be they members of Parliament/Congress, or the larger populace), they use epideictic rhetoric that celebrates the common values and achievements of their people. This enables the presidents to draw on the commonalities of their audiences in order to convince them. For the most part, epideictic rhetoric in the speeches serves as an occasion to associate with the audiences.

On the other hand, deliberative rhetoric is largely used in the speeches to dissociate from political opponents. Since many of the proposals and policy recommendations in the speeches are contestable, the presidents use lexical items that exclude portions of the audiences (the opposition party) while consolidating their own power as presidents, as well as the position of the political parties they represent. Even in cases where there are calls for bipartisanship, the eventual goal is to legitimize the power positions of the presidents. In instances where wandering "we" is used, the goal appears to be ambiguity, either because excluding the audience negatively affects the presidents' intended goal or it will be seen as politically inexpedient to do so. Overall, there seems to be, in many ways, a correlation between the use of inclusivity and epideictic rhetoric on the one hand, and exclusivity and deliberative rhetoric. As a presidential rhetorical genre, therefore, the SONA appears to be just as partisan as any other type of presidential rhetoric. Presidents use it to promote their own political agendas.

Overall, the interdisciplinary approach to the analysis of the texts through the use of rhetoric and (critical) discourse analysis, demonstrates how texts that are meant to be 
persuasive (e.g. the SONA) could also at the same time be used to exercise political power differentials. Rhetoric provided the macro dimensions of the texts"persuasion and other effects of texts" (Andrus, 2013, p. 4976) while (critical) discourse analysis provided the linguistic details that reveal the exercise of power in the texts. Both approaches therefore revealed both the persuasive character and the power relation characteristic of SONAs, and thus useful for the analysis of such texts.

This thesis has also been situated within comparative rhetoric, where the goal has been to investigate how adopted rhetorical genres such as the SONA are influenced by socio-cultural factors. The evidence from the text suggests that some norms and expectations of traditional leadership (Dovlo, 2004) and communication (Yankah, 1998) are still relevant in contemporary Ghanaian political spheres and therefore transferred to same. For instance, the longstanding function of religion in traditional, Ghanaian society as a force of social cohesion is transferred into modern, postcolonial Ghanaian political discourse where it not only serves a cohesive function, but also becomes a tool of manipulation in the hands of political actors. Within the Ghanaian context, therefore, echoes of precolonial norms of communication and power that might be seen in contemporary Ghanaian modes of communication could become useful in analyses of power relations. Here, Critical Discourse Analysis could benefit from this "cultural [basis] of discursive power" (Hum and Lyon, 2013, p. 154). As Mao (2015) argues, it is important for comparative rhetoricians to consider the "historicity, specificity, and incongruity" of rhetorical texts (2014, p. 450). The socio-cultural exigencies that determine rhetorical practices in a Ghanaian context 
include religion, which also constitutes a critical factor in the analysis of power. Scholars could thus re-envision how power works by examining the uses of religion in rhetoric not only for its effects on social cohesion but also for its manipulative potential in political discourse within a postcolonial nation. Scholars in comparative rhetoric and Critical Discourse Analysis could therefore find this important social factor useful both in the analysis of rhetorical strategies within a Ghanaian, nonWestern context as well as discussions of power differentials in same.

\subsection{Suggestions for Future Research}

The analysis has focused on a limited set of speeches by both presidents due to time and space constraints. This could be a limitation in terms of the generalizability of the findings. I therefore suggest that future research in this area diachronically explore a larger corpus of SONA in Ghana (especially since a corpus-based analysis of this genre of presidential speech is largely under-researched) to determine whether there are variations based on the year of tenure in which the address is delivered, or the particular political party in office. Comparative analyses of the addresses in other African countries could also be conducted to determine whether there are variations in this adopted genre of speech in postcolonial African countries.

Further, other traditional socio-cultural features that dictate contemporary Ghanaian (and African) norms of communication could be explored and included in future analyses. This would help uncover the influence of a wider array of African cultural norms and expectations of speaking on formal speech in English in postcolonial 
English-speaking African countries. This way, research can better account for nonWestern rhetorical practices in the addresses.

More importantly, the themes that emerge in these addresses are worthy of scholarly consideration. Scholars could explore theme-based rhetorical discourse analyses to uncover how discourses present and perpetuate political parties' hegemonic control. For instance, the 2014 SONA by President John Mahama is structured on the same four pillars of development programme he identified as his government's priorities in the 2013 address. This offers an opportunity for scholars to investigate how rhetorical strategies are used to sustain particular ideologies through intertextuality of the addresses. Finally, from the point of view of reception studies, the audience could be included in future analyses to determine how the speeches affect audiences in various ways.

\subsection{Conclusion}

From the analysis, two major issues become significant. First, borrowed rhetorical genres in non-Western contexts are underlain by local social-cultural norms, which in turn determine the tenor of their use. It is critical, therefore, that scholars pay attention to such norms and expectations if analyses are to better reflect the particularities of use of rhetorical practices in these contexts. Second, we can see that the presidents closely ally themselves with their audiences and persuade them by linking inclusivity to a greater good, be it democracy, continental leadership, education, and glorious achievements, all of which are resonances of the epideictic 
nature of the speeches. That notwithstanding, there is a predominance also of more deliberative rather than epideictic rhetoric in these speeches, which further point to the fact that although they might look less partisan on the surface and as a genre, they could be non-conciliatory, and are often used to achieve overtly political ends.

Through its analysis of examining how linguistic means are bent towards rhetorical ends, approaches such as a culturally sensitive Rhetorical Discourse Analysis could, therefore, be critical in unpacking the subtle power relations that often go unnoticed in political discourse. 


\section{References}

Agyekum, K. (2004). Aspects of Akan persuasive language. RASK-International Journal of Language and Communication, 21, 63-96.

Andrus, J. (2013). Rhetorical discourse analysis. In C.A. Chapelle (Ed.), The encyclopedia of applied linguistics (pp. 4975-4981). Oxford: Blackwell.

Aristotle. (2006). On rhetoric: A theory of civic discourse. (G.A. Kennedy, Trans.). Oxford: Oxford University Press.

Billig, M. (1999). Critical discourse analysis and conversation analysis: An exchange between Michael Billig and Emanuel A. Schegloff. Discourse \& Society, 10 (4), 543-582.

Bokor, M. J. (2014). When the drum speaks: The rhetoric of motion, emotion, and action in African societies. Rhetorica: A Journal of the History of Rhetoric, 32(2), 165-194.

Bramley, N. (2001). Pronouns of politics: The use of pronouns in the construction of 'self' and 'other' in political interviews. Unpublished PhD Thesis, Australian National University.

Burke, K. (1969). A rhetoric of motives. Berkeley, CA: University of California Press.

Campbell, K. E. (2006). Rhetoric from the ruins of African antiquity. Rhetorica: A Journal of the History of Rhetoric, 24 (3), 255-274. 
Campbell, K. K., \& Jamieson, K. H. (2008). Presidents creating the presidency: Deeds done in words. Chicago: University of Chicago Press.

Cheng, M. (2006). Constructing a new political spectacle: Tactics of Chen Shuibian's 2000 and 2004 inaugural speeches. Discourse \& Society, 17(5), 583608.

Chilton, P. (2004). Analysing political discourse: Theory and practice. London and New York: Routledge.

Chilton, P. (2005). Missing links in mainstream CDA. In R. Wodak and P. Chilton (Eds.), A new agenda in (critical) discourse analysis: theory, methodology and interdisciplinarity (pp. 19-51). Amsterdam/Philadelphia: John Benjamins Publishing.

Constitution of the Republic of Ghana, Article 67.

Dovlo, E. (2004). Religion and politics in Africa: The Ghanaian case. In S.E. Quianoo (Ed.), Africa Through Ghana Lenses (pp. 201-218). New York: SUNY Press.

Duszak, A. (2002). Us and others: An introduction. In A. Duszak (Ed.), Us and others: Social identities across languages, discourses and cultures (pp. 1-28). Amsterdam and Philadelphia: John Benjamins.

Eisenhart, C. \& Johnstone, B. (2008). Discourse analysis and rhetorical studies. In B. Johnstone and C. Eisenhart (Eds.), Rhetoric in detail: Discourse analyses of 
rhetorical talk and text (pp. 3-24). Amsterdam/Philadelphia: John Benjamins Publishing.

Essel, O. Q., Agyarkoh, E., Sumaila, M. S., \& Yankson, P. D. (2014). TVET stigmatization in developing countries: Reality or fallacy. European Journal of Training and Development Studies, 1(1), 27-42.

Fairclough, N. (2013). Critical discourse analysis: The critical study of language. London: Routledge.

Fairclough, N. (2015). Language and power. (3 $3^{\text {rd }}$ ed.). London: Routledge.

Foss, S. K., \& Griffin, C. L. (1995). Beyond persuasion: A proposal for an invitational rhetoric. Communications Monographs, 62 (1), 2-18.

Friedman, S.S. (2011). Why not compare? PMLA, 126 (3), 753-762.

GhanaWeb. (2009, March 13). I wish Ghana were a prayer camp-Mills. GhanaWeb. Retrieved from http://www.ghanaweb.com/GhanaHomePage/NewsArchive/Iwish-Ghana-were-a-prayer-camp-Mills-159010

Harutyunyan, V., \& Odame, E. (2015). Improving midwifery care worldwide. The Lancet, 385(9962), 25-26.

Helmbrecht, J. (2002). Grammar and function of we. In A. Duszak (Ed.), Us and others: Social identities across languages, discourses and cultures (pp. 31-49). Amsterdam and Philadelphia: John Benjamins. 
Huckin, T., Andrus, J., \& Clary-Lemon, J. (2012). Critical discourse analysis and rhetoric and composition. College Composition and Communication, 64 (1), 107-129.

Hum, S., \& Lyon, A. (2009). Recent advances in comparative rhetoric. In A.A Lunsford, K.H. Wilson, and R.A. Eberly (Eds.), The Sage Handbook of Rhetorical Studies (pp. 153-165). London: Sage.

Íñigo-Mora, I. (2004). On the use of the personal pronoun we in communities. Journal of Language and Politics, 3(1), 27-52

Johnstone, B. \& Eisenhart, C. (Eds.). (2008). Rhetoric in detail: Discourse analyses of rhetorical talk and text. Amsterdam/Philadelphia: John Benjamins Publishing.

Kress, G.R. and van Leeuwen, T. (2002). Multimodal Discourse: The modes and media of contemporary communication. London: Edward Arnold.

Lazar, M. M. (2007). Feminist critical discourse analysis: Articulating a feminist discourse praxis 1. Critical Discourse Studies, 4(2), 141-164.

Lin, A.M.Y. (2013). Critical discourse analysis: Overview. In C. A. Chapelle (Ed.), The encyclopedia of applied linguistics (pp. 1466-1471). Oxford: Blackwell.

Mao, L. (2014). Thinking beyond Aristotle: The turn to how in comparative rhetoric. PMLA, 129 (3), 448-455. 
Mao, L., Wang, B., Lyon, A., Jarratt, S. C., Swearingen, C. J., Romano, S., Simonson, P., Mailloux, S. \& Lu, X. (2015). Manifesting a future for comparative rhetoric. Rhetoric Review, 34 (3), 239-274.

Nelson, J. A. (2009). The Republican rhetoric of identification with gay and lesbian voters in the 2000 presidential campaign. Atlantic Journal of Communication, $17(2), 53-71$.

Obeng, S. G. (1997). Language and politics: Indirectness in political discourse. Discourse \& Society, 8(1), 49-83.

Pennycook, A. (1994). The politics of pronouns. ELT Journal, 48(2), 173-178.

Petersoo, P. (2007). What does 'we' mean? National deixis in the media. Journal of Language and Politics, 6(3), 419-436.

Roitman, M. (2014). Presidential candidates' ethos of credibility: The case of the presidential pronoun I in the 2012 Hollande-Sarkozy debate. Discourse \& Society, 25(6), 741-765.

Rosencrans, K. (2014). Nurturing faith for action: Theological education and global responsibility. Dialog, 53(4), 304-311.

Schegloff, E. A. (1997). Whose text? Whose context? Discourse \& Society, 8(2), $165-$ 187. 
Scheibman, J. (2004). Inclusive and exclusive patterning of the English first person plural: Evidence from conversation. In M. Achard \& S. Kemmer (Eds.), Language, Culture and Mind (377-396). Stanford, CA: CSLI Publications.

Shogan, C.J. (2015). The president's state of the union address: Tradition, function, and policy implications. Congressional Research Service. Retrieved from http://www.fas.org/sgp/crs/misc/R40132.pdf

Smith, L.T. (2012). Decolonizing methodologies: Research and indigenous peoples. (2nd Ed.), London: Zed Books.

Smith, S. H., Whitehead, G. I., Melo, A., Correa, A., \& Inch, M. (2014). Selfpresentational strategies of modern and traditional US presidents in state of the union and inaugural addresses. North American Journal of Psychology, 16 (1), 13-24.

State of the nation address 2013. Retrieved from http://www.parliament.gh/assets/file/State\%20of\%20Nation\%20Address/STA TE-OF-THE-NATIONS-ADDRESS-2013.pdf

State of the union address 2013. Retrieved from https://www.whitehouse.gov/the-press-office/2013/02/12/remarks-presidentstate-union-address

Sowinska, A. (2013). A critical discourse approach to the analysis of values in political discourse: The example of freedom in President Bush's State of the Union addresses (2001-2008). Discourse and Society, 24 (6), 792-809. 
Teten, R. L. (2003). Evolution of the modern rhetorical presidency: Presidential presentation and development of the State of the Union address. Presidential Studies Quarterly, 33(2), 333-346.

U.S. Constitution, Article II, Section 3.

van Dijk, T. A. (1993). Principles of critical discourse analysis. Discourse \& society, $4(2), 249-283$.

van Leeuven, T. (2005). Three models of interdisciplinarity. In R. Wodak and P. Chilton (Eds.), A new agenda in (critical) discourse analysis: theory, methodology and interdisciplinarity (pp. 3-18). Amsterdam/Philadelphia: John Benjamins Publishing.

Wodak, R (2001). The discourse-historical approach. In R. Wodak and M. Meyer (Eds.), Methods of Critical Discourse Analysis (pp. 63-84). London: Sage.

Wodak, R., \& Meyer, M. (2016). Critical discourse studies: History, agenda, theory and methodology. In R. Wodak and M. Meyer (Eds.), Methods of Critical Discourse Studies (pp. 2-22). London: Sage.

Yankah, K. (1991). Power and the circuit of formal talk. Journal of Folklore Research, 1-22.

Yankah, K. (1995). Speaking for the chief: Okyeame and the politics of Akan royal oratory. Indiana: Indiana University Press. 
Yankah, K. (1998). Free speech in traditional society: The cultural foundations of communication in contemporary Ghana. Accra: Ghana University Press.

Yankah, K. (2012). The proverb in the context of Akan rhetoric. New York: Diasporic Africa Press.

Zarefsky, D. (2014). Presidential rhetoric and the power of definition. Presidential Studies Quarterly, 34 (3), 607-619. 